\title{
Catabolite Repression of $\beta$-Galactosidase Synthesis in Escherichia coli
}

\author{
By V. MOSES AND C. PREVOST \\ Lawrence Radiation Laboratory, University of California, Berkeley, California, U.S.A.
}

(Received 20 December 1965)

\begin{abstract}
1. Repression by glucose of $\beta$-galactosidase synthesis is spontaneously reversible in all strains of Escherichia coli examined long before the glucose has all been consumed. The extent of recovery and the time necessary for reversal differ among various strains. Other inducible enzymes show similar effects. 2. This transient effect of glucose repression is observed in constitutive $\left(i^{-}\right)$and permease-less $\left(\mathrm{y}^{-}\right)$cells as well as in the corresponding $\mathrm{i}^{+}$and $\mathrm{y}^{+}$strains. 3 . Repression is exerted by several rapidly metabolizable substrates (galactose, ribose and ribonucleosides) but not by non-metabolized or poorly metabolized compounds (2-deoxyglucose, 2-deoxyribose, phenyl thio- $\beta$-galactoside and 2-deoxyribonucleosides). 4. The transient repression with glucose is observed in inducible cells supplied with a powerful inducer of $\beta$-galactosidase synthesis (e.g. isopropyl thio- $\beta$-galactoside) but not with a weak inducer (lactose); in the latter instance glucose repression is permanent. Diauxic growth on glucose plus lactose can be abolished by including isopropyl thio- $\beta$-galactoside in the medium. 5 . In some strains phosphate starvation increases catabolite repression; in others it relieves it. Adenine starvation in an adenine-requiring mutant also relieves catabolite repression by glycerol but not that by glucose. Restoration of phosphate or adenine to cells starved of these nutrients causes a pronounced temporary repression. Alkaline-phosphatase synthesis is not affected by the availability of adenine. 6. During periods of transient repression of induced enzyme synthesis the differential rate of RNA synthesis, measured by labelled uracil incorporation in 2 min. pulses, shows a temporary rise. 7. The differential rate of uracil incorporation into RNA falls during exponential growth of batch cultures of $E$. coli. This is equally true for uracil-requiring and non-requiring strains. The fall in the rate of incorporation has been shown to be due to a real fall in the rate of RNA synthesis. The significance of the changes in the rate of RNA synthesis is discussed. 8. A partial model of catabolite repression is presented with suggestions for determining the chemical identification of the catabolite co-repressor itself.
\end{abstract}

The inducible synthesis of a variety of bacterial catabolic enzymes has long been known to be influenced by the nutritional state of the cells. Growth of cells in media containing very rapidly metabolized sources of carbon results in the relative repression of the synthesis of enzymes such as $\beta$-galactosidase and L-tryptophanase, even though the appropriate inducers are also present. Repression of this type is responsible for the diauxic form of growth (Monod, 1945) observed, for example, when cells of Escherichia coli are supplied with a mixture of glucose and lactose; many examples of such diauxic growth patterns are known.

It gradually came to be realized that this repression, called originally the 'glucose effect', was by no means confined to glucose. Repression was found under a wide variety of conditions in which, as a general rule, carbohydrate consumption (i.e. catabolism) exceeded the cells' requirements for biosynthetic purposes (Neidhardt, 1960). It was thus observed with many rapidly metabolized substrates, or under conditions in which protein synthesis was partially decreased by the presence of inhibitors or by nutritional deficiencies. Magasanik (1963) therefore proposed a more general title of 'catabolite repression' for the phenomenon.

Kinetically, it has almost universally been accepted that the repression continues as long as the rapidly metabolized carbohydrate is present and the metabolic imbalance remains (see, for example, the kinetic graphs in McFall \& Mandelstam, .1963). However, Boezi \& Cowie (1961) reported a case in which spontaneous recovery from repression occurred, even though 
the glucose or other carbohydrate had not been exhausted. Although these authors did not pursue this observation, it seemed to us that a transitory effect of this type, rather than a terminal or permanent repression, offered more hope of success in studying the metabolic origins of the glucose inhibition. The present paper reports on a detailed investigation of transient repression and its relation to other physiological phenomena.

\section{MATERIALS AND METHODS}

Organisms. The following strains of $E$. coli were used; their relevant genetic characteristics are noted: $\mathrm{C600-1}$ $\left(i^{+} y^{-} z^{+}\right)$(from A. B. Pardee); AB $1105\left(i^{+} y^{-} z^{+}\right.$gal- $B_{1}^{-}-$

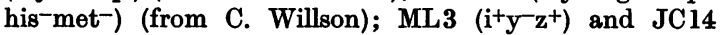
$\left(i^{+} y^{-} z^{+} a d e^{-}\right.$mey $)$(both from A. J. Clark); ML30 $\left(i^{+} y^{+} z^{+}\right)$, $300 \mathrm{U}\left(\mathrm{i}^{+} \mathrm{y}^{-} \mathrm{z}^{+}\right)$and $230 \mathrm{U}\left(\mathrm{i}^{-} \mathrm{y}^{-} \mathrm{z}^{+}\right)$(all from J. Monod); CR34 (thr-leu-met-thy-U $\mathrm{U}^{-} \mathrm{B}_{1}^{-}$) (from D. M. Freifelder); Cavalli ( $i^{+} y^{+} z^{+}$mey-thy $)$(from Aleen Simmons). Two $y^{+}$ revertants (AB1105-1 and $A B 1105-2)$ were isolated from AB 1105 by selection on lactose-agar. An alkaline-phosphatase constitutive mutant (JC14-2) was isolated from JC14 by the method of Torriani \& Rothman (1961).

Culture conditions. Cells were grown at $37^{\circ}$ in M63 medium (Pardee \& Prestidge, 1961) containing glycerol or succinate $(22 \mathrm{mM})$, and supplemented with specific nutrients as necessary. Vigorous aeration was provided by Tefloncoated bar magnets rapidly rotated by magnetic-stirrer motors below the flasks. The maltose medium of Boezi \& Cowie (1961) has also been used for the ML strains as noted in the text.

Enzyme induction and assay. Inducers for $\beta$-galactosidase, L-tryptophanase and D-serine deaminase were IPTG* (0.5 mM), L-tryptophan $(2.5 \mathrm{mM})$ and D-serine $(2.9 \mathrm{mM})$ respectively. Samples $(0.2 \mathrm{ml}$.) of cultures for $\beta$-galactosidase and alkaline-phosphatase assay were mixed with $20 \mu \mathrm{l}$. of chloramphenicol solution ( $1 \mathrm{mg} . / \mathrm{ml}$.). Later one drop of toluene was added and after vigorous agitation for 20 sec. with a Vortex Mixer the enzyme was measured by the rate of hydrolysis of $o$-nitrophenyl $\beta$-Dgalactoside for $\beta$-galactosidase (Kepes, 1963), or $p$-nitrophenyl phosphate (at pH8.0) for alkaline phosphatase.

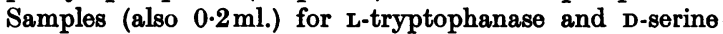
deaminase were assayed as described by Pardee \& Prestidge (1961). One unit of enzyme activity is defined for each enzyme as that amount of enzyme catalysing the hydrolysis of $1 \mathrm{~m} \mu \mathrm{mole}$ of substrate/min. at $37^{\circ}$.

Growth. This was determined by measurement of extinction at $650 \mathrm{~m} \mu$ in a $1 \mathrm{~cm}$. cuvette with a Beckman DK-2 double-beam spectrophotometer. Extinction was directly proportional to total protein under all conditions studied (cf. Fig. 20); at extinction 1.0, $1 \mathrm{ml}$. of culture contained $225 \mu \mathrm{g}$. of protein.

Chemical determinations. Samples of suitable volume for total protein and RNA were mixed with sufficient ice-cold trichloroacetic acid to give final concn. 5\% (w/v). RNA was extracted by heating the cells in trichloroacetic acid to $90^{\circ}$ for $15 \mathrm{~min}$., and was determined by the method of Schneider (1957). The residue was washed free from

* Abbreviation: IPTG, isopropyl thio- $\beta$-D-galactopyranoside. trichloroacetic acid, dried and dissolved in $\mathrm{N} \cdot \mathrm{NaOH}$; protein was determined as described by Lowry, Rosebrough, Farr \& Randall (1951).

Residual glucose in the medium was determined, after removal of the cells, by the Glucostat enzyme method (Worthington Biochemical Corp., Freehold, N.J., U.S.A.).

Labelling with radioactive precursors. Pulse-labelling experiments were performed by mixing $0.5 \mathrm{ml}$. of cell suspension with $10 \mu \mathrm{l}$. of an aqueous solution containing L-[G-14C]phenylalanine $(0 \cdot 25 \mu \mathrm{C}$; sp. activity $1 \mu \mathrm{C} / \mu \mathrm{mole})$ plus $\left[{ }^{3} \mathrm{H}\right]$ uracil $(2 \mu \mathrm{C}$; sp. activity $2600 \mu \mathrm{c} / \mu$ mole). After $2 \mathrm{~min}$. at $37^{\circ}, 2 \mathrm{ml}$. of ice-cold $6 \cdot 25 \%(\mathrm{w} / \mathrm{v})$ trichloroacetic acid was added, and the suspension kept at $0^{\circ}$ for at least $30 \mathrm{~min}$. The precipitate was then filtered through a prewetted Millipore membrane filter $(0.45 \mu$ pore size), washed repeatedly with cold trichloroacetic acid followed by water, and after being sucked roughly dry the whole filter was dissolved with agitation in scintillation solution (Kinard, 1957). This solution was gelled by the addition of Cab-O-Sil Thixotropic Gel Powder (Packard Instrument Co. Inc., Downers Grove, Ill., U.S.A.), maintaining the precipitate in suspension. Samples were counted in a Packard Tri-Carb Scintillation Counter by using an external standard. Occasionally $\mathrm{L}-\left[\mathrm{Me}-{ }^{14} \mathrm{C}\right]$ methionine was used as the labelled amino acid.

In experiments requiring measurement of radioactivity in the supernatant medium, the cells were removed by filtration through a dry Millipore membrane filter as above, and measured volumes of filtrate assayed in the scintillation counter.

Chemicals and radiochemicals. IPTG, o-nitrophenyl $\beta$-D-galactopyranoside, $p$-nitrophenyl phosphate, 2-deoxyglucose, 2-deoxyribose, D-serine and L-tryptophan were obtained from Calbiochem, Los Angeles, Calif., U.S.A.; chloramphenicol was from Parke, Davis and Co., Detroit, Mich., U.S.A.; phenyl thio- $\beta$-D-galactopyranoside was a gift from Dr C. Willson. Other chemicals were standard commercial products.

$\mathrm{L}-\left[\mathrm{G}-{ }^{14} \mathrm{C}\right]$ Phenylalanine, $\mathrm{L}-\left[\mathrm{Me}-{ }^{14} \mathrm{C}\right]$ methionine and $\left[{ }^{3} \mathrm{H}\right]$ uracil were obtained from New England Nuclear Corp., Boston, Mass., U.S.A.; D-[14C]glucose was prepared by the method of Putman \& Hassid (1952).

\section{RESULTS}

Transient repression of $\beta$-galactosidase synthesis by glucose. The effect on the inducible synthesis of $\beta$-galactosidase of adding glucose $(10 \mathrm{~mm})$ has been investigated in seven inducible strains of $E$. coli. In each case, as reported by Boezi \& Cowie (1961), glucose was only temporarily effective in repressing enzyme synthesis. In a period that varied widely between different strains (Fig. 1), the differential rate of enzyme synthesis increased after an initial repression, and in some cases nearly reached the rate found in the absence of glucose. The length of the repression period varied from about $4 \mathrm{~min}$. with strains ML 3 and M30 (Fig. 1) to $150 \mathrm{~min}$. with AB 1105 (Fig. 19). Paigen (1964) in a brief note has also described mutants exhibiting the property of transient repression.

The carbon content of the medium was almost 


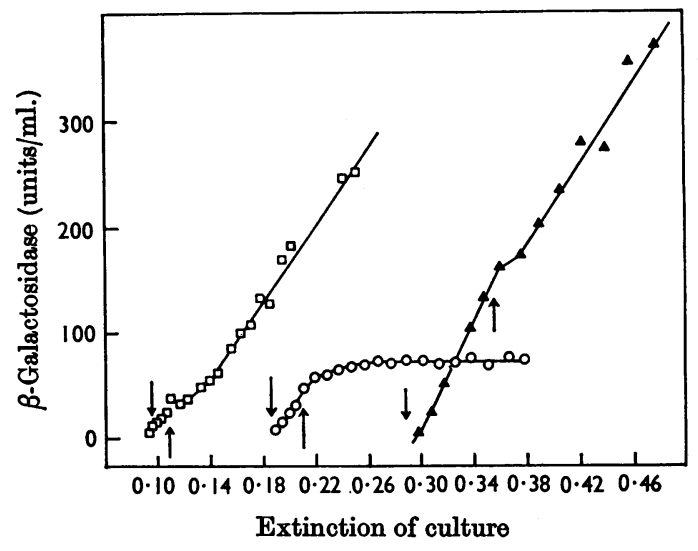

Fig. 1. Transient glucose repression of $\beta$-galactosidase synthesis in three strains of $E$. coli. In each case IPTG $(0.5 \mathrm{~mm})$ was added $(\downarrow)$ followed 15 or $20 \mathrm{~min}$. later by glucose $(10 \mathrm{~mm})(\uparrow)$. Differential activity of $\beta$-galactosidase plotted. Mass doubling times (min.) before and after glucose addition, and length of transient repression respec-

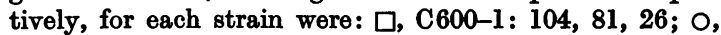
AB1105: 77, 57, >45; $\triangle$, ML3: 67, 52, 4 .

doubled by the addition of glucose. Fig. 2 shows that the glucose concentration did not fall significantly until long after the end of the transient repression.

The relation between the time at which glucose was supplied to the cells, relative to the time of adding the inducer, may be predicted from the existence of the transient. The experimental results are shown in Fig. 3. Glucose added during $\beta$ galactosidase synthesis resulted in a transient repression which lasted in that experiment about 22min. (Fig. 3C). Adding glucose together with inducer delayed the attainment of a constant differential rate of enzyme synthesis from the characteristic 3min. (Pardee \& Prestidge, 1961) to $27 \mathrm{~min}$. (Fig. $3 B$ ). When glucose was added $40 \mathrm{~min}$. before inducer only the usual $3 \mathrm{~min}$. delay was observed (Fig. 3A). These results suggest that metabolic rearrangements occur when glucose is added to the cells, and that it is this readjustment, rather than glucose metabolism itself, which is responsible for the greatest degree of inhibition of enzyme synthesis. The final steady rate of enzyme synthesis in the presence of glucose, while lower than in its absence, was invariably two or more times greater than the rate during maximum inhibition.

Glucose transient during growth on carbon sources other than glycerol. Fig. 1 has already shown the glucose transient repression with strain ML 3 growing on glycerol-minimal media. A similar response to glucose was shown when ML 3 grew on

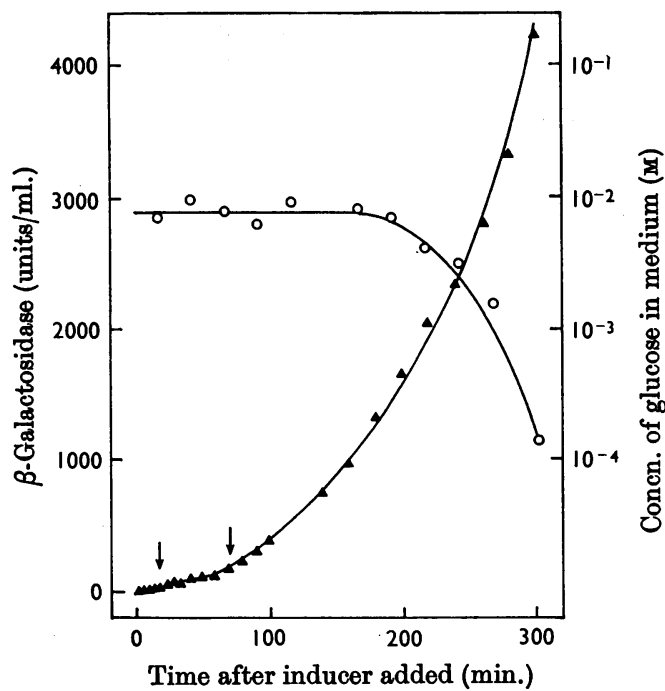

Fig. 2. Kinetics of transient repression of $\beta$-galactosidase synthesis and utilization of glucose in exponentiallygrowing cells of strain C600-1. IPTG (0.5 mM) added at zero time, glucose $(10 \mathrm{~mm})$ added $16 \mathrm{~min}$. later. Transient repression started at the first arrow, when glucose was added; maximum degree of recovery was completed at the second arrow after $55 \mathrm{~min}$. $\Delta, \beta$-galactosidase activity; $O$, concn. of glucose in the medium.

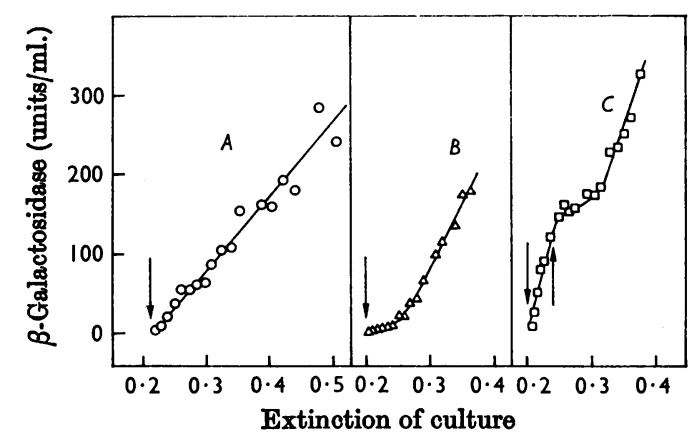

Fig. 3. Glucose (10 mm) and IPTG $(0.5 \mathrm{~mm})$ added at various times to Cavalli strain. $A$, glucose added $40 \mathrm{~min}$. before IPTG (arrow shows IPTG addition); $B$, glucose and IPTG added simultaneously at arrow; $C$, IPTG added at $\downarrow$, glucose added $20 \mathrm{~min}$. later at $\uparrow$.

succinate or maltose (Fig. 4). There was thus no special effect of glucose on glycerol-grown cells.

Elimination of the diauxic growth pattern. A further prediction of the transient response is that cells supplied with glucose and lactose should no longer grow in a diauxic manner if IPTG is also present in the medium. This was indeed found to be the case (Fig. 5), and may probably be explained in the following manner. Competition between 


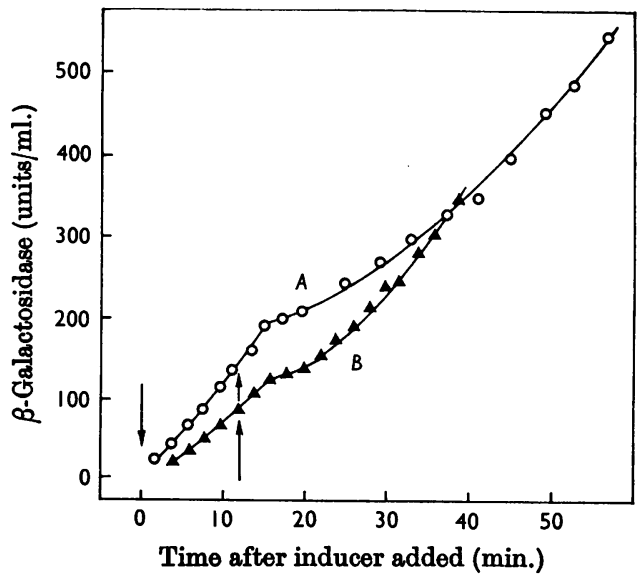

Fig. 4. Transient glucose repression of $\beta$-galactosidase synthesis in succinate- and maltose-grown cells of ML3. IPTG added at $\downarrow$; glucose added at $\uparrow . A(0)$, succinategrown cells; $B(\Delta)$, maltose-grown cells.

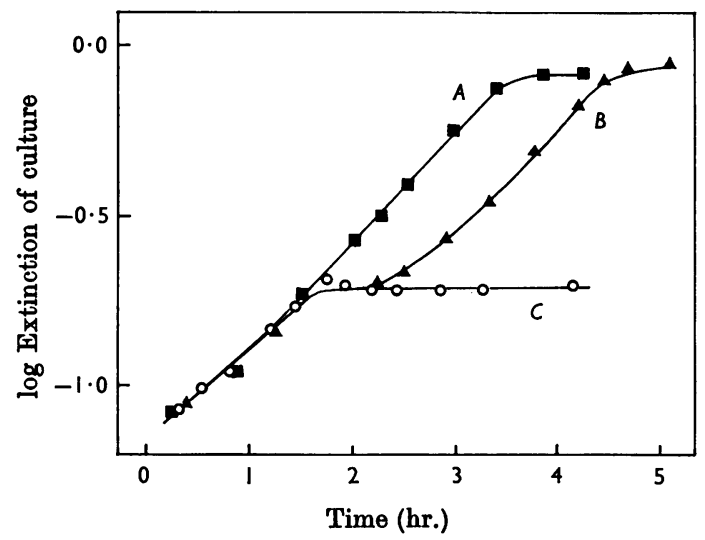

Fig. 5. Abolition of diauxie. Cavalli strain cells were grown under the following conditions: $A(\square)$, glucose + lactose +IPTG; $B(\Delta)$, glucose + lactose; $C(0)$, glucose alone.

catabolite repression exerted by glucose and $\beta$ galactosidase induction has been demonstrated by Clark \& Marr (1964). IPTG is known to be a more powerful inducer than lactose for the enzymes of the lactose operon; i.e. higher concentrations of these enzymes are induced by equal concentrations of IPTG and lactose (Jacob \& Monod, 1961). Glucose repression thus becomes more effective with a weak inducer than with a strong one, and IPTG seems to be strong enough to prevent most of the glucose inhibition, whereas lactose is not. At the end of the glucose phase of growth, cells grown with IPTG have sufficient enzyme to permit immediate utilization of lactose. Those without IPTG must start to synthesize enzyme in the absence of an available carbon source. This can only be done slowly, so that the resumption of growth on lactose is delayed.

Effects of glucose and the entry of inducer into the cell. A possible explanation for the glucose transient repression would reside in the mechanism of glucose transport into the cell. It was suggested to us by Dr A. L. Koch (personal communication) that glucose and IPTG might be transported into and out of the cell by the same non-specific carrier system. Addition of glucose to the medium would result in the sudden flooding of glucose into the cell, with the liberation on the inside of many available free carrier molecules. These might then eject from the cell a large number of inducer molecules, thereby slowing the rate of induced enzyme synthesis. After a time it might be supposed that the intermediary pools of glucose metabolism would become saturated, and this would result in a fall in the rate of glucose entry. Some inducer molecules would then be able to regain entry and induced enzyme synthesis would to some extent be restored.

In support of this theory we must note that Kepes (1960) did observe a lowering of the internal inducer concentration in cryptic cells in the presence of glucose. Unfortunately, Kepes's (1960) results are open to criticism. Inducer uptake was measured by the accumulation in the filterable cell fraction of radioactivity from labelled inducer (methyl thiogalactoside). It was not shown that this radioactivity was inside the cells, as distinct from being adsorbed on the surface; above all, there was no way of measuring the effective inducer concentration at the induction site. A dense, nongrowing cell suspension was employed (just how dense is not clear from the paper) in which the cells were poisoned with chloramphenicol. Some doubt would arise in applying his findings to a viable and growing population.

In the present studies we have investigated the ability of a number of compounds other than glucose to cause transient repression. Substances tested have included galactose, ribose, uridine, adenosine, cytidine and guanosine. All of these are metabolized by the cells and all produce transient repression. However, 2-deoxyglucose, 2-deoxyribose and 2-deoxyribonucleosides are not rapidly metabolized and produce no transient repression. Deoxyribose is degraded by $\boldsymbol{E}$. coli to ethanol, acetate and carbon dioxide (Bernstein, Fossitt \& Sweet, 1958). None of these substances would be expected to cause severe catabolite repression. 2-Deoxyglucose is known to be phosphorylated in $E$. coli (Gershanovich, 1962), and to inhibit growth 


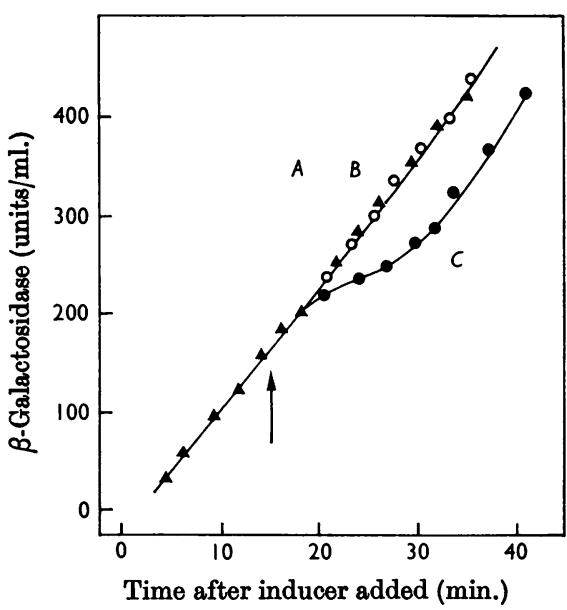

Fig. 6. Effect of non-metabolizable and metabolizable substances on $\beta$-galactosidase synthesis in ML3. Exponentially growing cells were supplied with IPTG $(0.5 \mathrm{~mm})$ at zero time. Subsequent additions made $15 \mathrm{~min}$. later: $A$ ( $\Delta)$, phenyl thio- $\beta$-D-galactoside (1 mM); $B(0), 2$ deoxyglucose (1 mM); $C(\bullet)$, glucose (1 mM).

in high concentration (Schick, Landau \& Tschudy, 1958). It must therefore enter the cells, but we have found that it has no effect on $\beta$-galactosidase synthesis (Fig. 6). Cohn \& Horibata (1959) have also shown that 2-deoxyglucose did not preferentially inhibit $\beta$-galactosidase synthesis under conditions in which glucose abolished it almost entirely.

A more rigorous test of the expulsion theory would consist of supplying the cells with a compound similar in structure to the inducer but not itself active in promoting enzyme induction. With IPTG as inducer a convenient compound to test is phenyl thio- $\beta$-galactoside, which has no inducing capacity (Jacob \& Monod, 1961). Phenyl thiogalactoside, at a concentration of $1 \mathrm{~mm}$ compared with $0.5 \mathrm{~mm}$ for IPTG in the same culture, produced no detectable repression in either strain ML 3 or $300 U$ (Fig. 6). Demonstration of the penetration of phenyl thiogalactoside was performed by adding it to a $45 \%(\mathrm{v} / \mathrm{v})$ suspension of cells, and determining its concentration in the supernatant, after removal of the cells, by its extinction at $245 \mathrm{~m} \mu$. The concentration of phenyl thiogalactoside in the whole suspension was $0.14 \mathrm{mM}$; the measured concentration in the supernatant was $0.15 \mathrm{~mm}$. It may thus be calculated that about $84 \%$ of the volume of the packed cells was available to penetration by phenyl thiogalactoside. While these experiments do not support expulsion of inducer as a factor in transient repression, it should be noted that these observations, like those of Kepes (1960), do not unequivocally distinguish between penetration of the

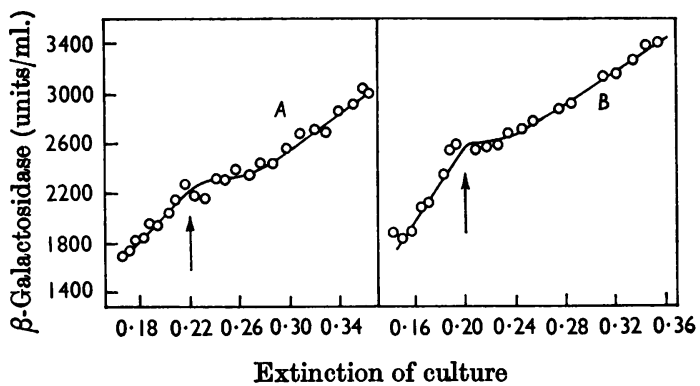

Fig. 7. Effect of mutation at the regulator gene on transient repression. Glucose added to exponentially growing cultures of strains $230 \mathrm{U}\left(\mathrm{i}^{-}\right)$or $300 \mathrm{U}\left(\mathrm{i}^{+}\right)$, induced with IPTG. Glucose addition is shown by arrows. $A, 230 \mathrm{U}$; $B, 300$ U.

substance into the cells and adsorption on to the surface. The absence of effect of phenyl thiogalactoside directly contradicts the findings of Herzenberg (1959), who, in the same strain of cells, found an inhibition of $20-40 \%$ of $\beta$-galactosidase synthesis but reported no kinetic experiments of this inhibition.

Effect of mutation at the regulator gene locus. The effects of glucose on the synthesis of $\beta$-galactosidase were compared in inducible $\left(i^{+}\right)$and constitutive $\left(i^{-}\right)$strains. Though it is, for technical reasons, more difficult to obtain scatter-free kinetic curves with a constitutive than with an inducible strain, the results demonstrate no significant difference between the glucose transients with the two strains (Fig. 7).

Effect of mutation at the permease gene locus. Comparison of strains isogenic except for the galactoside permease gene (y) showed no difference between $\mathrm{y}^{+}$and $\mathrm{y}^{-}$; strain ML 30 was compared with ML 3, and AB1105 with AB 1105-1 or AB 1105-2. This again excludes entry of inducer as a factor in repression, except in the sense that glucose repression of the lactose operon would presumably inhibit the synthesis of galactoside permease as well as $\beta$-galactosidase itself. Such an effect on permease was not studied in detail, and would in any case be of no consequence in the $y^{-}$mutants.

Elimination of the $i$ and $y$ genes as being controlling factors in producing the transient repression shifted attention to aspects of glucose metabolism itself.

Nutritional deficiencies and catabolite repression. (i) Phosphate. Clark \& Marr (1964) reported that starvation of cells for sulphate, an essential inorganic nutrient, resulted in catabolite repression of $\beta$-galactosidase, and McFall \& Magasanik (1962) observed a similar effect with phosphate starvation. We have studied the effects of phosphate starvation 


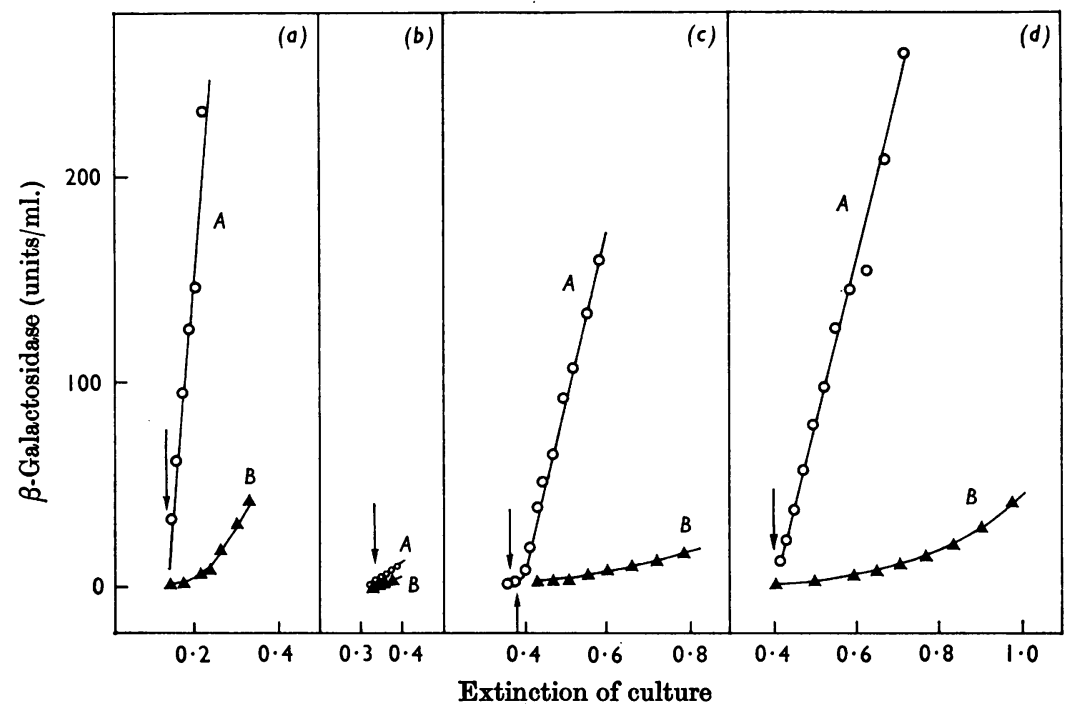

Fig. 8. Inorganic phosphate nutrition and the effects of glucose on $\beta$-galactosidase synthesis in strain AB 1105. (a) Adequate phosphate, IPTG added at $\downarrow: A$, no glucose; $B$, with glucose. (b) During phosphate starvation, IPTG added at $\downarrow: A$, no glucose; $B$, with glucose. (c) Addition of phosphate ( $\uparrow$ ) to phosphatestarved cells $20 \mathrm{~min}$. after IPTG added $(\downarrow): A$, no glucose; $B$, with glucose. (d) IPTG ( $\downarrow)$ added to phosphatestarved cells $20 \mathrm{~min}$. after restoration of inorganic phosphate: $A$, no glucose; $B$, with glucose.

on two strains of $E$. coli and found variable effects, depending on the strain used.

Fig. 8 shows the findings with AB 1105, a strain more sensitive than most to glucose repression (Fig. 1). During growth on glycerol in the presence of adequate phosphate (Fig. 8, section $a$ ) the differential rate of enzyme synthesis was high (2300 enzyme units/ml. of culture/extinction of culture at $650 \mathrm{~m} \mu$ ); simultaneous addition of glucose and IPTG resulted in a period of $65 \mathrm{~min}$. of very slow enzyme production, and then the rate of synthesis increased to 350 enzyme units $/ \mathrm{ml}$. of culture/extinction. When the phosphate was exhausted, growth slowed down from a doubling time of $84 \mathrm{~min}$. to one of $660 \mathrm{~min}$. At this point alkaline phosphatase synthesis was de-repressed, indicating that the concentration of inorganic phosphate had fallen to less than $10 \mu \mathrm{M}$ (Torriani, 1960). During phosphate starvation induction with IPTG resulted in a very low rate of enzyme synthesis (190 units/ml. of culture/extinction), which was depressed still further by glucose to 46 units/ml. of culture/extinction (Fig. 8, section b). Addition of inorganic phosphate (10 $\mathrm{mm}$ ) to phosphate-starved cells supplied $20 \mathrm{~min}$. earlier with IPTG resulted in a rapid increase in the rate of enzyme synthesis, which reached $840 \mathrm{units} / \mathrm{ml}$. of culture/extinction in $23 \mathrm{~min}$. The presence of glucose, however, prevented this rise, and the rate of enzyme synthesis with IPTG plus glucose was still only 70 units $/ \mathrm{ml}$. of culture/extinction $100 \mathrm{~min}$. after the addition of phosphate (Fig. 8, section c). After the addition of phosphate to starved cells, the growth rate increased, and exponential growth with a doubling time of $107 \mathrm{~min}$. was achieved in about $80 \mathrm{~min}$. (see Fig. 9 for a similar experiment). IPTG added $20 \mathrm{~min}$. after phosphate rapidly induced enzyme synthesis, which achieved a value of $860 \mathrm{units} / \mathrm{ml}$. of culture/extinction. In the presence of glucose this was much decreased, and $120 \mathrm{~min}$. after the addition of IPTG (equal to $140 \mathrm{~min}$. after the replacement of phosphate) the rate with glucose present was still only 135 units/ ml. of culture/extinction (Fig. 8, section $d$ ). These results confirm the observations of Clark \& Marr (1964) that deprivation of essential inorganic ions may enhance catabolite repression.

Restoration of the pre-starvation state of metabolism permitting enzyme synthesis was rapidly achieved when phosphate was supplied to the cells, provided that glucose was not also present. The lower post-starvation differential rate of enzyme synthesis may be correlated with a lower growth rate after starvation until the end of the experiment. We may conclude that this relatively high degree of catabolite repression even in the absence of glucose observed in the post-starvation period, coupled with an alteration of glucose 
metabolism at that time, resulted in the intense repression in the presence of glucose shown in sections $c$ and $d$ of Fig. 8.

Glucose utilization, measured by the disappearance of $\left[{ }^{14} \mathrm{C}\right]$ glucose from the medium, was determined at various stages during growth on limiting phosphate (Fig. 9). It was found that the rate of glucose utilization paralleled the rate of growth rather closely throughout the experiment, showing that the enhanced repression exerted by glucose during phosphate starvation was due not to a

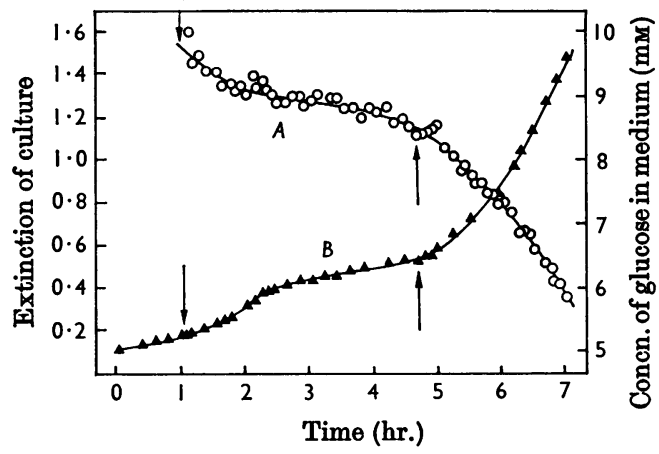

Fig. 9. Utilization of glucose during phosphate starvation in AB 1105. Glucose added at $\downarrow$; inorganic phosphate added at $\uparrow$. $A$, glucose conon. in medium; $B$, extinction of culture.

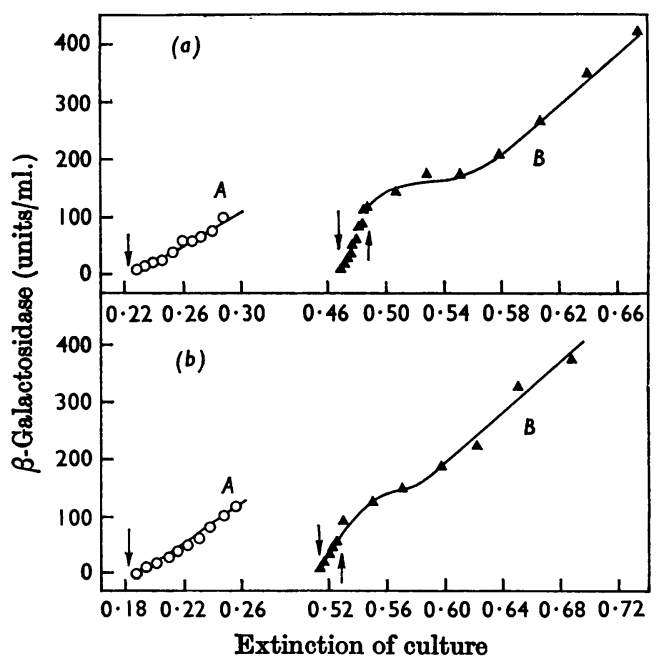

Fig. 10. Synthesis of $\beta$-galactosidase in JC14 before, during and after starvation for adenine or phosphate. (a) Limiting adenine; (b) limiting phosphate. $A$, before exhaustion of limiting nutrient, IPTG added at $\downarrow ; B$, during exhaustion of limiting nutrient, IPTG added at $\downarrow$; limiting nutrient replaced $30 \mathrm{~min}$. later at $\uparrow$. relative increase in glucose consumption compared with growth, but rather to a rearrangement of internal metabolism during this period.

The situation in strain JC14, an adenine and methionine auxotroph, was different (Fig. 10). In this organism phosphate starvation relieved catabolite repression due to glycerol in the medium, since the rate of enzyme synthesis increased from 1650 enzyme units $/ \mathrm{ml}$. of culture/extinction, in the presence of phosphate, to 5300 enzyme units $/ \mathrm{ml}$. of culture/extinction in its absence. Replacement of phosphate produced a rapid growth response, whereas $\beta$-galactosidase showed a transitory period of severe repression followed by recovery, some $33 \mathrm{~min}$. after phosphate was added, to a synthesis rate of 2135 units $/ \mathrm{ml}$. of culture/extinction.

The respiration of the cells on the glycerol used as growth substrate was studied manometrically during the various states of phosphate nutrition. Periodically, duplicate $2 \mathrm{ml}$. samples of the growing culture were introduced into Warburg flasks, one of which contained sufficient chloramphenicol $(50 \mu \mathrm{g} . / \mathrm{ml}$. $)$ to prevent further enzyme synthesis. Oxygen consumption at $37^{\circ}$ was measured after absorption of respiratory carbon dioxide with potassium hydroxide. Initially, respiration was identical in both flasks of each pair, indicating that chloramphenicol had no effect on the rate of oxygen uptake. In time, of course, cells without chloramphenicol increased in quantity, and the oxygen uptake in those flasks increased in rate. The results in Table 1 show that the specific rate of respiration was much decreased during the period of phosphate starvation. This is presumably due to a shortage of available phosphate for intermediary compounds required in the respiratory processes, and suggests that such compounds are also required for the maintenance of catabolite repression. Addition of inorganic phosphate (4 mM) caused an immediate increase in the rate of oxygen absorption even in the presence of chloramphenicol.

Phosphate starvation produces quite different responses with regard to catabolite repression in the two strains JC14 and AB1105. One must conclude that the balance of metabolism in the two strains differs considerably as far as phosphate dependence is concerned.

(ii) Adenine. The de-repressing effect on JC14 of phosphate starvation, having suggested an involvement with phosphorylation processes, prompted us to study in another way an impairment of phosphorylating activity. Since most phosphorylations require the participation of ATP we have made use of the adenine requirement of JC14 to try to deplete the intracellular availability of ATP.

The effects of adenine starvation in cells supplied with glycerol were strongly reminiscent of those of phosphate starvation (Fig. 10). The differential 
Table 1. Effect of adenine and phosphate starvation on the rates of growth, respiration and $\beta$-galactosidase synthesis in the adenine-requiring strain JC 14

Cells were grown with limiting quantities of adenine or inorganic phosphate. Samples of the cultures were removed before the essential nutrient was exhausted, during starvation, and after restoration of the nutrient. In each case IPTG was added to part of the sample and the subsequent differential rate of $\beta$-galactosidase synthesis was measured. The remainder of the sample was treated with chloramphenicol (50 $\mu \mathrm{g}$. $/ \mathrm{ml}$.) and the respiration measured by conventional manometric techniques. Growth was measured by the extinction at $650 \mathrm{~m} \mu$ in a $1 \mathrm{~cm}$. cuvette.

Adenine supply:

$$
\begin{gathered}
\beta \text {-Galactosidase } \\
\text { synthesis } \\
\text { (units/extinction) }
\end{gathered}
$$

adequate

exhausted

restored

Phosphate supply:

adequate

exhausted

restored
1480

6500

2210

1650

5300

2140

$$
\begin{gathered}
\text { Oxygen uptake } \\
(\mu \mathrm{l} . / \mathrm{hr} . / \\
\text { extinction) }
\end{gathered}
$$

167
39

193

164

99

229
Growth

(generation/hr.)

$0 \cdot 76$

$0 \cdot 10$

0.79

0.97

0.08

$0 \cdot 86$

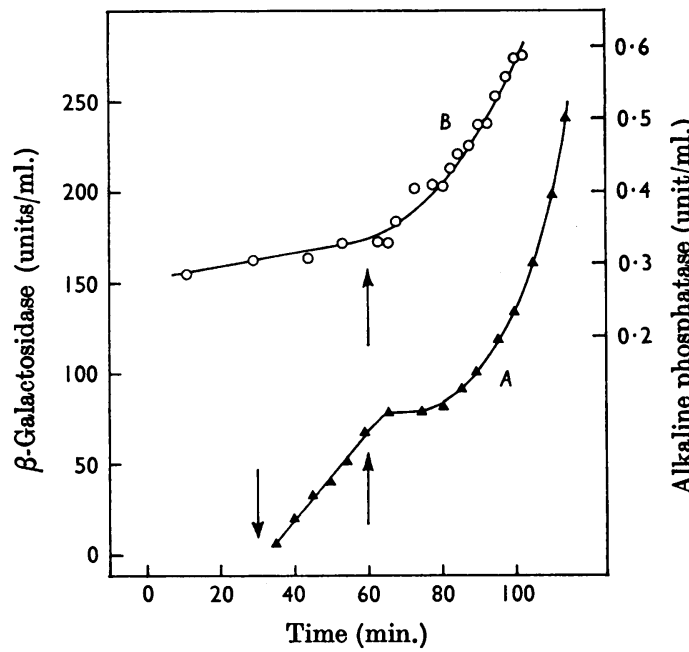

Fig. 11. Synthesis of $\beta$-galactosidase and alkaline phosphatase during and after adenine starvation in JC14-2. IPTG added at $\downarrow$; adenine added at $\uparrow . A, \beta$-Galactosidase; $B$, alkaline phosphatase.

induced rate of $\beta$-galactosidase synthesis increased from 1480 units $/ \mathrm{ml}$. of culture/extinction in the presence of adenine to $6500 \mathrm{units} / \mathrm{ml}$. of culture/ extinction when it limited growth. Growth itself was strongly inhibited (Table 1). On restoring the supply of adenine, growth was resumed, and after a period of intense repression lasting $45 \mathrm{~min}$. the rate of $\beta$-galactosidase formation recovered to a value of 2210 units $/ \mathrm{ml}$. of culture/extinction (Fig. 10). Respiration was even more strongly inhibited by adenine starvation than by phosphate deficiency
(Table 1), but also recovered immediately when adenine was supplied.

The inhibition of $\beta$-galactosidase synthesis by adding adenine to adenine-starved cells appeared to be due to catabolite repression, since alkalinephosphatase synthesis showed a constant differential rate through the whole course of adenine starvation and restoration (Fig. 11). In this experiment repression of $\beta$-galactosidase synthesis lasted about $25 \mathrm{~min}$. McFall \& Magasanik (1960) have shown that alkaline phosphatase is not subject to catabolite repression by carbon compounds.

Strain JC14 growing with all the required nutrients showed a typical repression transient when glucose was added to induced cells. When starved of adenine these cells were strongly and permanently (more than $150 \mathrm{~min}$.) repressed by glucose (Fig. 12).

(iii) Thymine. Cohen \& Barner (1955) as well as McFall \& Magasanik (1962) have shown that enzyme induction can take place in thyminedeficient cells. The latter authors found that after prolonged thymine deficiency catabolite repression developed after a fall in the rate of protein synthesis.

The recovery from glucose repression in thycells has now been studied in cultures with and without thymine. A strain of $E$. coli with requirements for both thymine and methionine was used. The cells were grown on glycerol-minimal medium supplemented with both essential nutrients. $\beta$ Galactosidase was induced in part of the culture with IPTG, and in two parallel flasks glucose was added either with inducer (curve $B$ ) or $20 \mathrm{~min}$. later (curve $A$ ) (Fig. 13). In the first case enzyme synthesis was delayed (cf. Fig. 3B), a constant differential rate of synthesis being reached some 


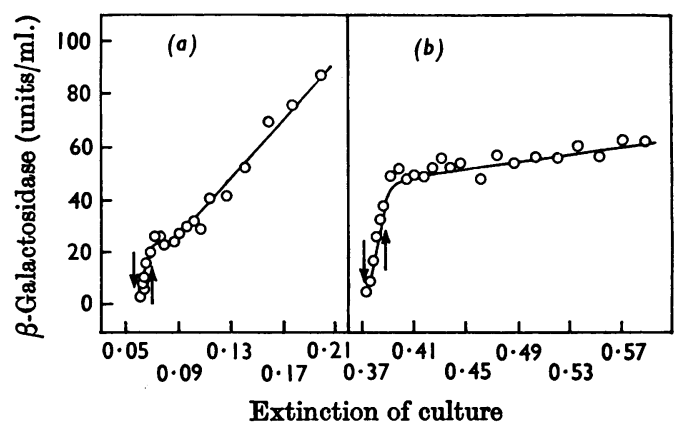

Fig. 12. Glucose repression of $\beta$-galactosidase synthesis as a function of adenine nutrition in JC14. IPTG added at $\downarrow$; glucose added at $\uparrow$. (a) With adequate adenine (transient repression lasted $24 \mathrm{~min}$.); (b) during adenine starvation (repression lasted more than $144 \mathrm{~min}$.).

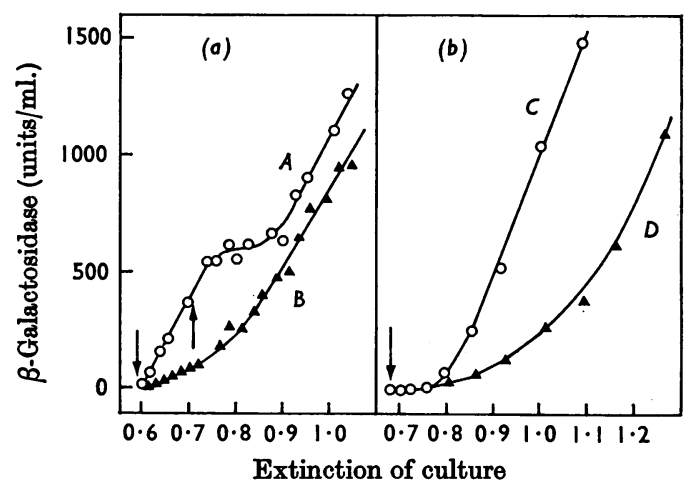

Fig. 13. Glucose repression of $\beta$-galactosidase synthesis as a function of thymine nutrition in Cavalli strain. (a) Adequate thymine; (b) during thymine starvation. $A$, IPTG added at $\downarrow$, glucose added at $\uparrow ; B$, IPTG and glucose added at $\downarrow ; C$, IPTG added at $\downarrow ; D$, IPTG and glucose added at $\downarrow$.

$40 \mathrm{~min}$. later than in the parallel flask without glucose. In the second case, a typical transient repression, lasting $25 \mathrm{~min}$., of $\beta$-galactosidase synthesis was observed.

The rest of the cells were centrifuged, washed twice and resuspended for $2 \mathrm{hr}$. in the same medium without methionine. This treatment permitted the completion of replication of DNA already in progress, but prevented initiation of further replication (Maaløe \& Hanawalt, 1961). The cells were washed again, resuspended in medium containing methionine but now devoid of thymine, and were distributed between two flasks. After $5 \mathrm{~min}$. of incubation, IPTG with or without glucose (10 mM) was added, and growth (by extinction), total protein and $\beta$-galactosidase activity were followed in each case. No growth occurred for $20 \mathrm{~min}$. in the absence of thymine. It then began slowly, becoming exponential by about $45 \mathrm{~min}$. and remaining so for over $60 \mathrm{~min}$. when the experiment was terminated. However, the doubling time was $97 \mathrm{~min}$. compared with $74 \mathrm{~min}$. in medium with thymine and methionine. Glucose did not increase the growth rate. Total protein was always directly proportional to extinction. $\beta$-Galactosidase synthesis in the absence of glucose started $35 \mathrm{~min}$. after IPTG was added, but the differential rate of synthesis did not become constant for a further $35 \mathrm{~min}$. (Fig. 13, curve $C$ ). In the presence of glucose enzyme synthesis started later, $45 \mathrm{~min}$. after the addition of IPTG, and the differential rate became approximately constant $60 \mathrm{~min}$. later still (Fig. 13, curve $D$ ).

Both before and during thymine starvation glucose repressed the final constant differential rate of enzyme synthesis by $10-20 \%$. It should be noted that during thymine starvation $\beta$-galactosidase in the absence of glucose was synthesized about 1.6 times as rapidly as when thymine was present.

Catabolite repression and the rate of synthesis of $R N A$. The rate of synthesis of RNA has been investigated in a number of physiological situations leading to catabolite repression. Sypherd \& Strauss (1963) have already shown an inverse relationship between RNA synthesis and repression during partial inhibition of protein synthesis by chloramphenicol.

Simultaneous pulse-labelling for $2 \mathrm{~min}$. at $37^{\circ}$ with a mixture of $\left[{ }^{3} \mathrm{H}\right]$ uracil and $\mathrm{L}-\left[\mathrm{G}-{ }^{14} \mathrm{C}\right]$ phenylalanine (or $\mathrm{L}-\left[\mathrm{Me}-{ }^{14} \mathrm{C}\right]$ methionine) has been used to measure the differential rate of RNA synthesis, i.e. the rate of RNA synthesis versus the rate of protein synthesis. We have invariably found experimentally that the rate of incorporation of $\left[{ }^{14} \mathrm{C}\right]$ phenylalanine into trichloroacetic acid-insoluble material is directly proportional to the extinction of the bacterial culture, so that the incorporation of $\left[{ }^{3} \mathrm{H}\right]$ uracil versus extinction of the culture may be used as a measure of the differential rate of RNA synthesis. The validity of pulse-labelling as a measure of RNA synthesis is discussed below.

RNA synthesis has been measured in adeninerequiring cells during adenine starvation, and after the restoration of adenine to starved cells (Fig. 14), in an experiment similar to those reported in Figs. 10 and 12. During adenine starvation the rate of synthesis was very low, consistent with a deficiency of adenine for ATP which is required both for energy and as a precursor of RNA. On addition of adenine, the differential rate of uracil incorporation increased some 18-fold within $2 \mathrm{~min}$. and declined thereafter, reaching an approximately steady-state value about $35 \mathrm{~min}$. later; this steady- 


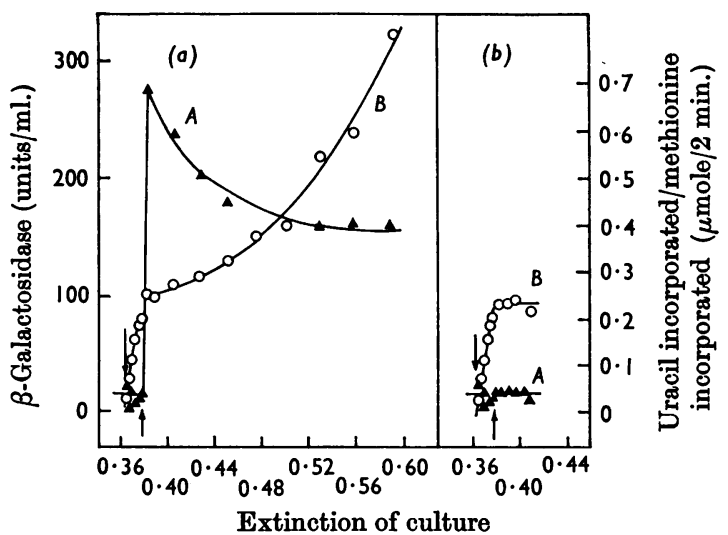

Fig. 14. Differential rates of uracil incorporation into RNA and of $\beta$-galactosidase synthesis in adenine-starved cells of JC14, before and after addition of adenine or glucose. (a) Addition of IPTG $(\downarrow)$ and adenine $(\uparrow)$; $(b)$ addition of IPTG $(\downarrow)$ or glucose $(\uparrow) . A,\left[{ }^{3} \mathrm{H}\right] \mathrm{Uracil} /\left[M e^{-14} \mathrm{C}\right]-$ methionine incorporated in $2 \mathrm{~min}$. pulses; $B, \beta$-galactosidase.

state rate was about nine times the rate during adenine starvation. Measurement of the differential rate of $\beta$-galactosidase synthesis in the same experiment showed that repression was greatest during the period of maximum RNA synthesis, and enzyme synthesis recovered to a new constant rate at almost exactly the time that RNA synthesis had declined to a steady-state rate. In this experiment the steady differential rate of $\beta$-galactosidase synthesis after adenine addition was $25 \%$ of the rate during adenine starvation. We conclude that the rearrangement of metabolism after addition of adenine which resulted in enhanced RNA synthesis was also responsible for repression of enzyme formation. The addition of glucose to adeninestarved cells (Fig. 14) totally repressed $\beta$-galactosidase synthesis (cf. Fig. 12) but had no effect on RNA synthesis.

It was decided to study also the behaviour of RNA synthesis during the typical transient repression of $\beta$-galactosidase synthesis in exponentially growing cells caused by glucose. When this was attempted, however, a new phenomenon was observed which must first be described. Although exponential growth on an extinction basis (and hence on a total protein basis) was observed to continue uninterruptedly in the culture for more than four generations, the differential rate of RNA synthesis rose some $30 \%$ from the beginning of the experiment to a peak value two generations later; in the next two generations it fell by $97 \%$ from the maximum value (Fig. 15). The effects of glucose on the rate of RNA synthesis must therefore be considered superimposed on this rising and falling

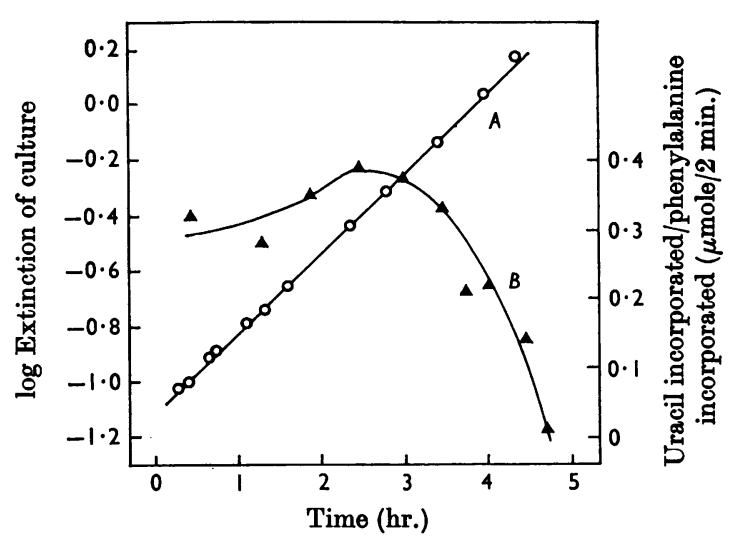

Fig. 15. Differential rate of uracil incorporation into RNA as a function of growth (as measured by extinction) of JC14. Concn. of growth supplements: adenine, $25 \mu \mathrm{g} . / \mathrm{ml}$; methionine, $50 \mu \mathrm{g} . / \mathrm{ml}$. $A, \log E_{650} ; B,\left[{ }^{3} \mathrm{H}\right]$ uracil incorporated/[14C]phenylalanine incorporated in $2 \mathrm{~min}$. pulses.

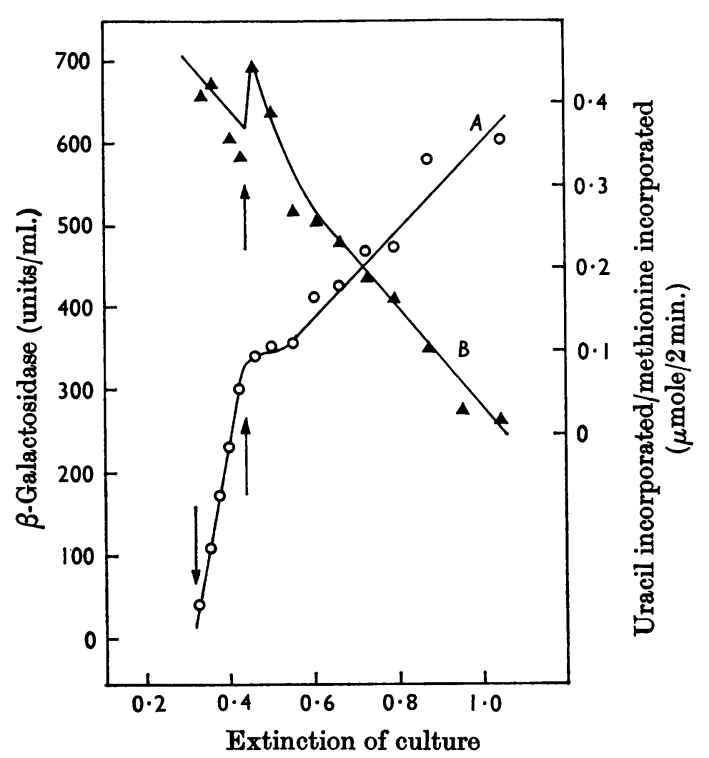

Fig. 16. Effect of glucose on differential rates of uracil incorporation into RNA, and of $\beta$-galactosidase synthesis, in exponentially growing cells of JC14. IPTG $(\downarrow)$ and glucose $(\uparrow)$ were added as indicated. $A, \beta$-Galactosidase; $B,\left[{ }^{3} \mathrm{H}\right]$ uracil/ $\left[M e^{-14} \mathrm{C}\right]$ methionine incorporated in $2 \mathrm{~min}$. pulses.

pattern normally occurring in the absence of glucose.

RNA synthesis during the glucose transient in four strains of $E$. coli showing transient effects of different durations was examined in exponentially 
growing cells (Figs. 16-19). Addition of glucose to each strain growing on glycerol increased the growth rate (cell divisions/hr.) by $20-30 \%$. The differential rate of RNA synthesis showed an immediate upward response, later declining towards the control values. There was a definite correlation between the transient effects of glucose on RNA synthesis and on $\beta$-galactosidase synthesis. With strains JC14 (Fig. 16) and C600-1 (Fig. 17), $\beta$-galactosidase recovery began when the rate of RNA synthesis was well past its peak. Strain ML 30 represents a special case, since the glucose repression transient effect was very short (4-5 min.) and this strain was obviously much less sensitive than the other three to glucose repression. Genetically the ML series of strains is different from the other three, which are all derivatives of $\mathrm{K}-12$. Nevertheless it can be seen from Fig. 18 that the peak of RNA synthesis was reached in a short time (not more than $5 \mathrm{~min}$.) and the rate declined rapidly thereafter. In strain AB 1105, one showing a prolonged glucose transient effect for enzyme synthesis, with relatively poor recovery, it should be noted (Fig. 19) that the differential rate of RNA

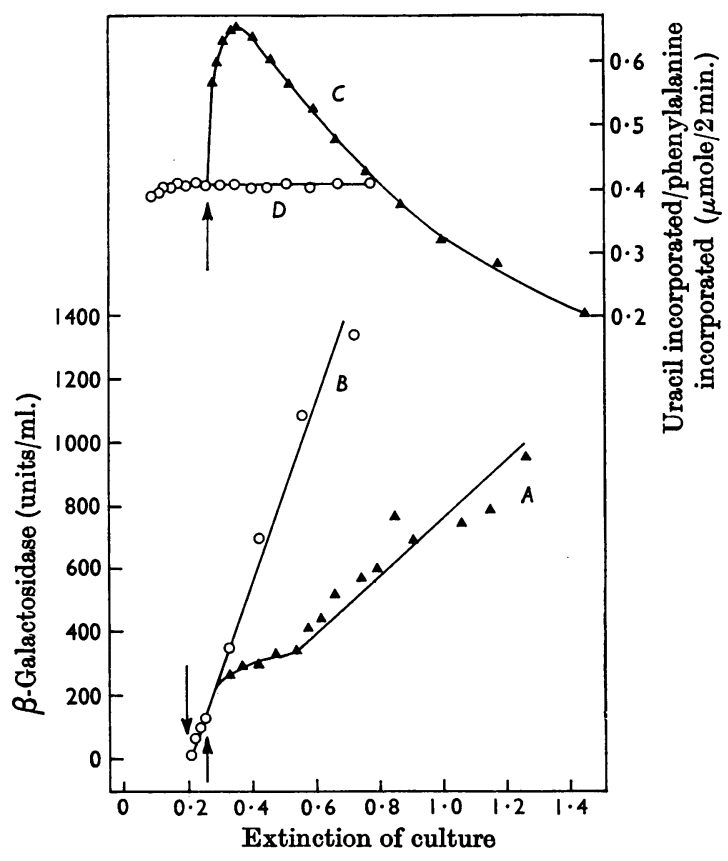

Fig. 17. Effect of glucose on differential rates of uracil incorporation into RNA, and of $\beta$-galactosidase synthesis, in exponentially growing cells of C600-1. IPTG $(\downarrow)$ and glucose $(\uparrow)$ were added as indicated. $A, \beta$-Galactosidase, added glucose; $B, \beta$-galactosidase with no glucose; $C$, $\left[{ }^{3} \mathrm{H}\right]$ uracil/ $\left[{ }^{14} \mathrm{C}\right]$ phenylalanine incorporated in $2 \mathrm{~min}$. pulses, added glucose; $D$, as $C$ with no glucose added.

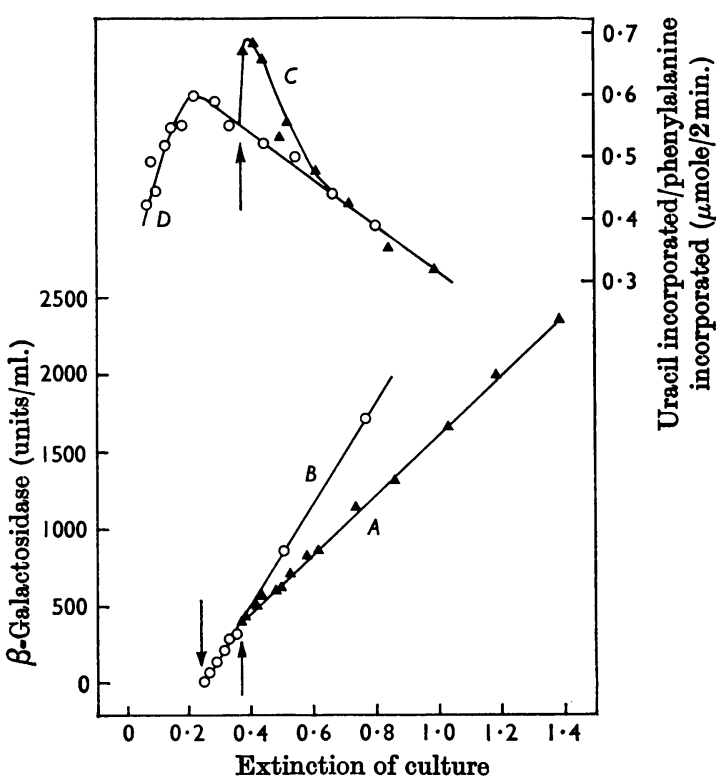

Fig. 18. Effect of glucose on differential rates of uracil incorporation into RNA, and of $\beta$-galactosidase synthesis, in exponentially growing cells of ML3. IPTG $(\downarrow)$ and glucose ( $\uparrow$ ) were added as indicated. $A, \beta$-Galactosidase, added glucose; $B, \beta$-galactosidase with no glucose; $C,\left[{ }^{3} \mathrm{H}\right]$ uracil/ [14 C]phenylalanine incorporated in $2 \mathrm{~min}$. pulses, added glucose; $D$, as $C$ with no glucose added.

synthesis never declined to the control value. The relatively high continuing rate of RNA synthesis might be related to the low rate of $\beta$-galactosidase synthesis attained after the period of repression.

Occasionally strain ML 30, growing on glucosefree maltose, showed no increase in growth rate on the addition of glucose. In such cases there was also neither transient repression of $\beta$-galactosidase synthesis nor transient stimulation of RNA synthesis.

Validity of pulse-labelling with $\left[{ }^{3} \mathrm{H}\right]$ uracil as a measure of the rate of $R N A$ synthesis. Pulse-labelling of bacterial cultures with labelled uracil has been widely used as a measure of the rate of RNA synthesis. From the paper of Levinthal, Keynan \& Higa (1962) it can be estimated that pulsing for 2 min. with uracil results in $50-60 \%$ of the radioactivity being incorporated into an unstable RNA fraction, the remainder residing in more stable species. The unstable fraction has often been equated with messenger RNA (Levinthal et al. 1962), but it must be recognized that, though all unstable RNA may have a messenger function, not all messenger RNA is necessarily unstable (Moses \& Calvin, 1965a,b; Yudkin, 1965).

In the present studies we have observed unequivocal changes in the specific rates of incorpora- 


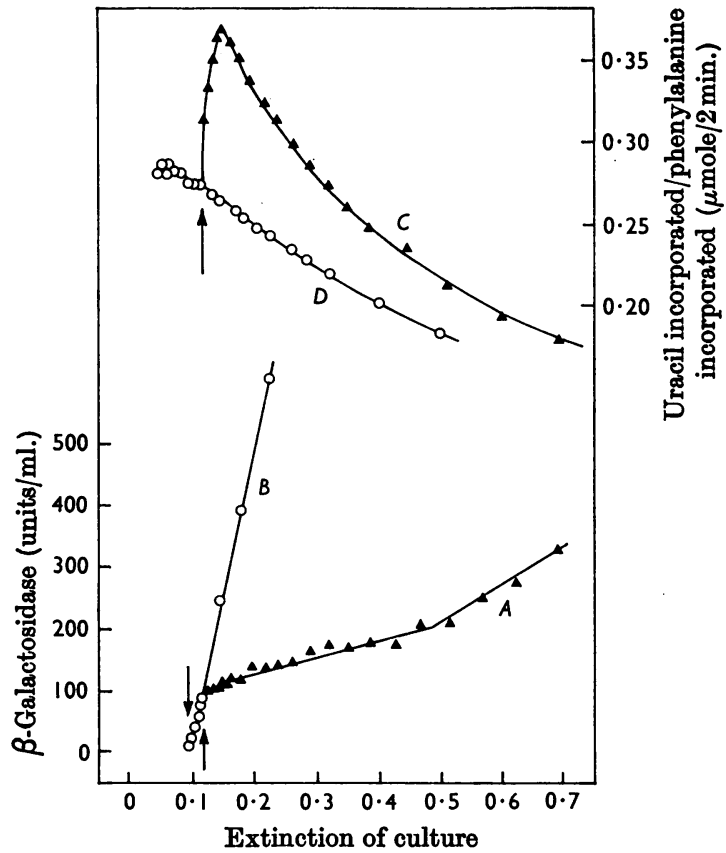

Fig. 19. Effect of glucose on differential rates of uracil incorporation into RNA, and of $\beta$-galactosidase synthesis, in exponentially growing cells of AB1105. IPTG $(\downarrow)$ and glucose $(\uparrow)$ were added as indicated. $A, \beta$-Galactosidase with glucose; $B, \beta$-galactosidase with no glucose; $C$, $\left[{ }^{3} \mathrm{H}\right]$ uracil/ $\left[{ }^{14} \mathrm{C}\right]$ phenylalanine incorporated in $2 \mathrm{~min}$. pulses, added glucose; $D$, as $C$ with no glucose added.

tion of $\left[{ }^{3} \mathrm{H}\right]$ uracil both as a result of continued growth and after glucose addition. Other interpretations, apart from changes in the rate of RNA synthesis, may be evoked to explain these findings. The organisms used were not uracil-requiring, and we have assumed that when supplied with external uracil they have used this in preference to endogenous uracil. McCarthy \& Britten (1962) have obtained evidence in support of this assumption, but they did not extend their observations to include cultures at different stages of development. Thus a possible explanation of the changes in uracil incorporation might be related to an alteration of the balance of the use of external versus endogenous uracil to make RNA. This has been examined by studying the uptake of $\left[{ }^{3} \mathrm{H}\right]$ uracil in a uracil-requiring mutant, in which only external uracil was available to the cell. Such an experiment is reported in Fig. 20.

Two parallel cultures of U- cells were grown under identical conditions in medium containing unlabelled uracil $(50 \mu \mathrm{g} . / \mathrm{ml}$.). To one culture a small quantity of $\left[{ }^{3} \mathrm{H}\right]$ uracil of high specific activity was added. By periodic measurements of residual

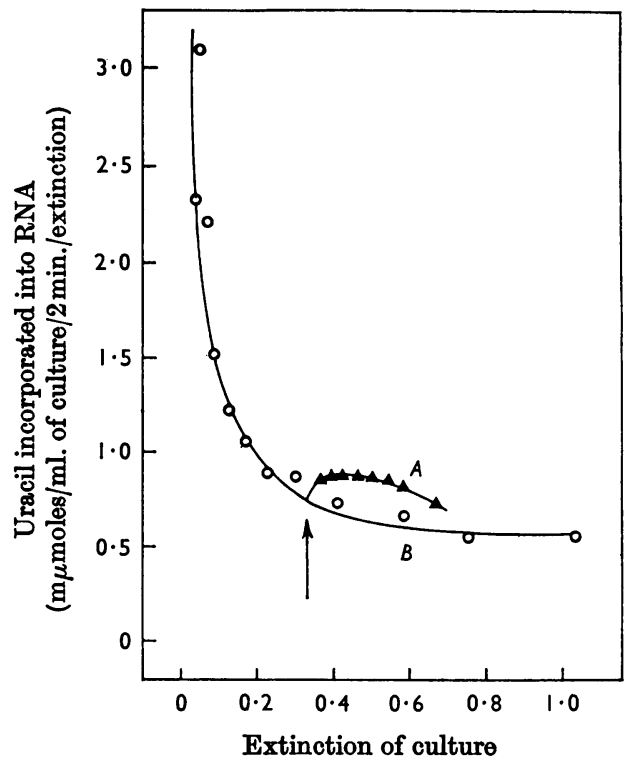

Fig. 20. Effect of glucose on the differential rate of uracil incorporation into RNA as a function of exponential growth of uracil-requiring cells (CR34). $A$, Glucose added at arrow; $B$, no glucose added.

radioactivity in the supernatant medium of the flask containing $\left[{ }^{3} \mathrm{H}\right]$ uracil the overall rate of utilization of uracil was determined; this was found to be directly proportional to growth as measured by extinction. Hence, when samples of the second culture were pulse-labelled with $\left[{ }^{3} \mathrm{H}\right]$ uracil, the specific activity of the labelled uracil at each stage could be calculated since the quantity of unlabelled uracil remaining in the medium was known. It was found that, like the $\mathrm{U}^{+}$strains, the uracilrequiring cells showed a declining differential rate of uracil incorporation into RNA as the culture became older; exponential growth was maintained through the whole course of this experiment. Glucose temporarily stimulated incorporation.

The use of uracil-requiring cells, however, poses a new difficulty. Although, as shown by McCarthy \& Britten (1962), U+ cells incorporate external uracil directly into RNA without equilibration with the internal uracil pool, this may not be the case with $\mathrm{U}$ - cells. In the latter the declining rate of incorporation of external $\left[{ }^{3} \mathrm{H}\right]$ uracil into RNA might have been the result of an increasing internal pool with which external uracil equilibrated, thus effectively lowering the specific activity of the labelled precursor. This aspect of the problem has been examined by measuring the effective intracellular pool of uracil by the method described by McCarthy \& Britten (1962). 
The method essentially is to study the kinetics of uracil incorporation into RNA as a function of time. If no equilibration with a pre-existing pool is necessary, uracil incorporation would be expected to be essentially linear (for short exposures to the labelled substrate), with the slope of incorporated uracil passing through the origin. Equilibration with an unlabelled pool would result in an increasing rate of uracil incorporation which would finally become maximal when the specific radioactivity of the pool was in equilibrium with that of the incoming precursor. Since the U- mutant depended for growth on uracil in the medium only a very small proportion of the total external uracil was incorporated into RNA in the course of a few seconds, and the problems of removing the enormous excess of label to count the incorporated ${ }^{3} \mathrm{H}$ proved insuperable at very low cell concentrations. It was thus not possible to study uracil pool sizes over the whole range of growth shown in Fig. 20. Satisfactory results were obtained, however, by the middle of the growth period, when the extinction had already reached values of 0.27 and more. Kinetic curves obtained at extinction values of 0.27 and 0.51 , by which stage the differential rate of RNA synthesis had fallen nearly to a minimum value (Fig. 20), failed to reveal any pool equilibration (Fig. 21). A change in the size of an equilibrating unlabelled pool may therefore be excluded as an explanation for the results of Fig. 20, and we may conclude with confidence that in both $\mathrm{U}^{+}$and $U^{-}$cells the fall in the differential rate of uracil incorporation reflected a real fall in the differential rate of RNA synthesis.

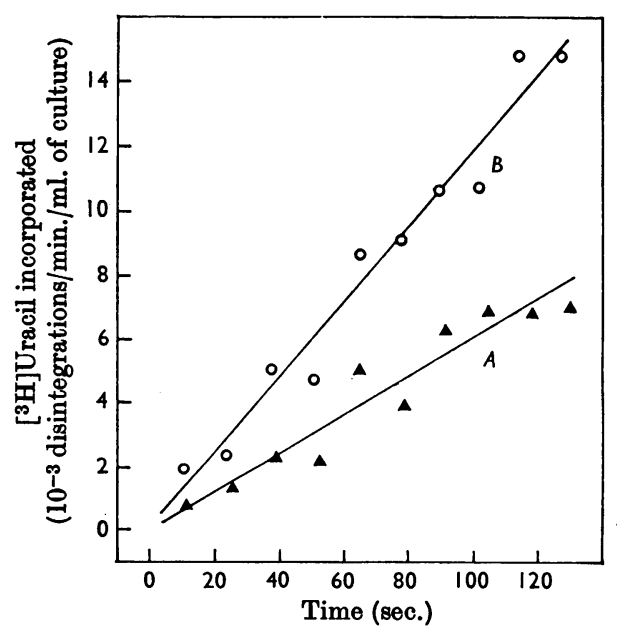

Fig. 21. Kinetics of uracil incorporation into RNA during exponential growth of a uracil-requiring strain (CR34). Extinction of culture: $A, 0.272 ; B, 0.513$.
Chemical determinations demonstrated that the total RNA of the cells was directly proportional to extinction and to total protein throughout the whole course of exponential growth, for extinction values at least as high as 1.9 (Fig. 22). The significance of these findings in relation to RNA turnover will be discussed below.

Effect of glucose in the absence of a source of nitrogen. Both Clark \& Marr (1964) and Nakada \& Magasanik (1964) have shown that catabolite repression is very severe in cells supplied with carbohydrate but devoid of a source of nitrogen. In view of our observations of the comparatively great resistance of strains ML3 and ML 30 to repression by glucose in growing cells, it was decided to investigate the behaviour of these strains in a condition of nitrogen starvation.

Exponentially growing cells were harvested, washed and resuspended in $0.1 \mathrm{M}$-phosphate buffer, $\mathrm{pH} 7 \cdot 2$, containing $0 \cdot 125 \mathrm{M}$-sodium chloride. After $20 \mathrm{~min}$. IPTG was added, followed $30 \mathrm{~min}$. later by glucose to concentration $10 \mathrm{~mm}$. Measurement of $\beta$-galactosidase activity (Fig. 23) showed that the addition of glucose resulted in an increase in the rate of enzyme synthesis. A slight increase in extinction was also observed after the addition of glucose.

Catabolite repression by glucose of other enzymes. Glucose repression of $\beta$-galactosidase synthesis in ML 30 was compared with effects on L-tryptophanase and D-serine deaminase (Fig. 24). Both these other enzymes showed spontaneous recovery from glucose repression, though the repression lasted longer than with $\beta$-galactosidase. The recovery times for the three enzymes were 4,18

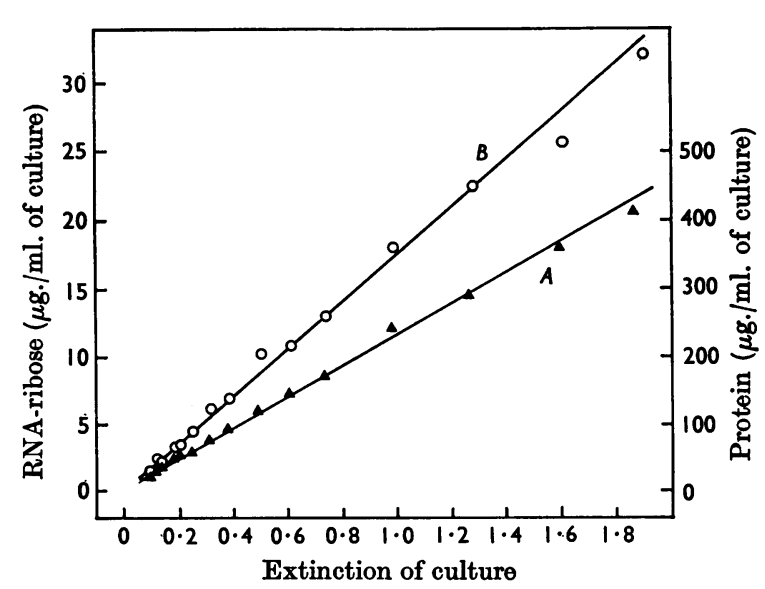

Fig. 22. Relation of extinction to total protein and to total RNA in C600-1. $A$, Total protein; $B$, total RNA (measured as ribose). Extinction measured in $1 \mathrm{~cm}$. cuvette at $650 \mathrm{~m} \mu$. 
and $54 \mathrm{~min}$. for $\beta$-galactosidase, serine deaminase and tryptophanase respectively.

\section{DISCUSSION}

Nature of cataboliterepression by glucose. Although catabolite repression of the lactose enzymes in $E$. coli has been extensively studied for many years a great deal of the mechanism by which the repression is exerted remains unclear. Nakada \& Magasanik

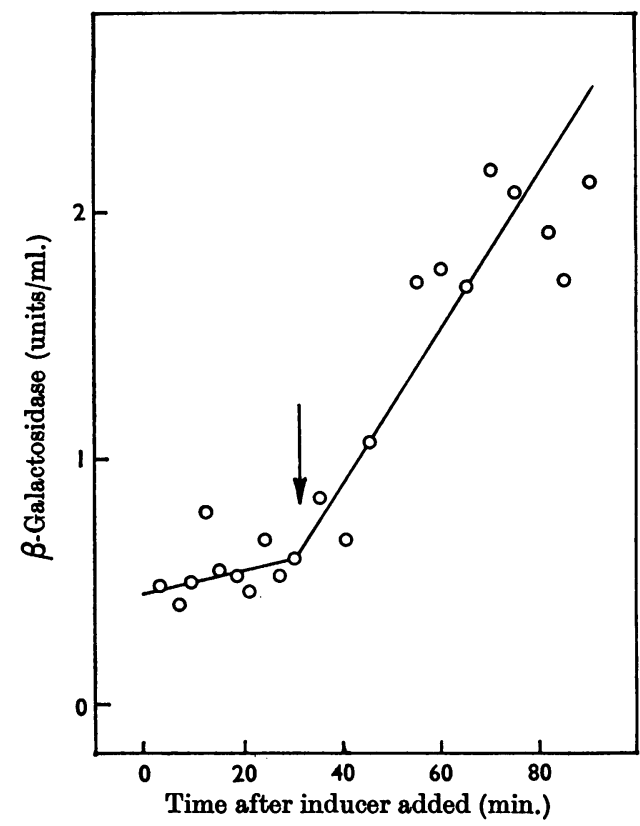

Fig. 23. Effect of glucose on $\beta$-galactosidase synthesis in nitrogen-starved cells of ML30. Cells starved in phosphate buffer, pH7·2. Glucose added at arrow.
(1964) have published very convincing evidence that the repression prevents the transcription of $\beta$-galactosidase messenger RNA, rather than the translation of that messenger molecule into protein. With two other aspects of catabolite repression we are on much less certain ground: the identity of the catabolite co-repressor itself, and the regulatory site at which it acts.

The realization that catabolite repression is to a large extent a transient phenomenon, with spontaneous recovery taking place even in the continued presence of the carbohydrate giving rise to the catabolite co-repressor, has enabled a fresh approach to be made in studying this question. A transient repression implies a temporary metabolic rearrangement when the cells are provided with a rich carbon source after a poor one, and evidence of several consequences of the rearrangement, and the establishment of a new steady state of metabolism, is provided in the present paper. In view of our observation that spontaneous recovery occurs when galactose is the repressing sugar we would need to contest the view of McFall \& Mandelstam (1963) that a derivative of this sugar is the co-repressor.

The existence of the transient effect in cells with non-functional regulator and permease genes (i.e. $i^{-}$and $y^{-}$) suggests at first sight that neither of these genes is involved with catabolite repression. Indeed, Loomis \& Magasanik (1964) claimed to have excluded entirely the regulator gene as the place where the co-repressor exerts its action. In fact, however, their results are less conclusive than that. They showed in conjugation experiments that catabolite repression was not dependent on the regulator gene product being present in sufficiently high concentration to confer inducibility, but they did not ensure the total absence of this product. We thus cannot exclude the possibility that catabolite repression is powerful enough to activate
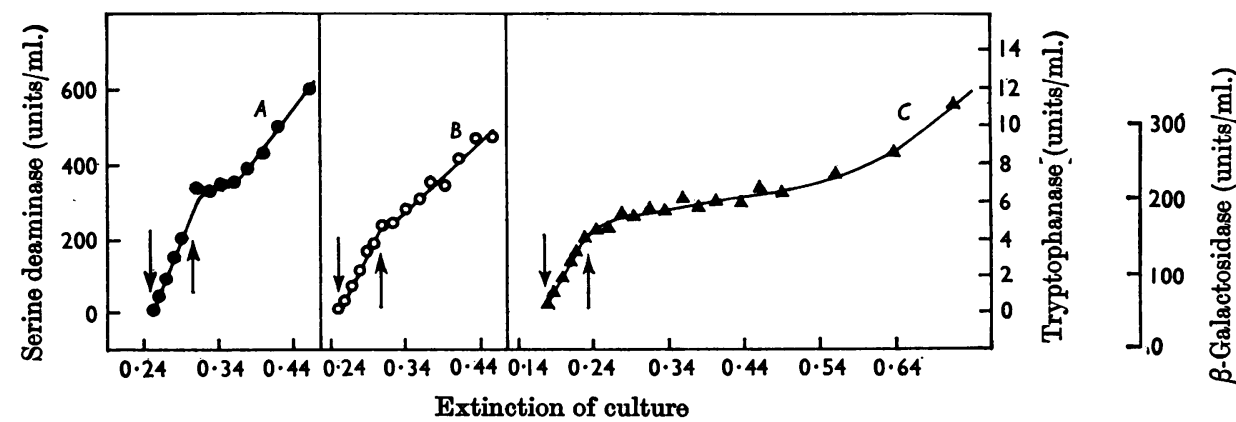

Fig. 24. Transient repression by glucose of the synthesis of three inducible enzymes in ML30. Inducers $(\downarrow)$ and glucose (10 mM) $(\uparrow)$ were added as shown. $A, D$-Serine deaminase (repression lasted 18min.); $B, \beta$-galactosidase (repression lasted $4 \mathrm{~min}) ;$.$C , L-tryptophanase (repression lasted 60-80 min.).$ 
repression by the regulator gene product even when the latter is present in too low a concentration to be effective by itself. Loomis \& Magasanik (1964) have already been criticized along these lines by Clarke \& Brammar (1964). The present observations have similarly shown that the transient repression is not directly connected with the normal functional ability of the regulator gene product to confer inducibility, but the $i$ gene product may yet have a role in catabolite repression in this connexion.

Whatever the site of co-repressor action, the competition between the inducer and co-repressor, described by Clark \& Marr (1964), has been confirmed in the present studies. Partial recovery from glucose repression was manifest when IPTG was the inducer, but not with lactose. This supports the contention that after the usual period of intense repression when glucose is added, which may be ascribed to a high concentration of co-repressor, recovery follows when the co-repressor concentration falls to a new steady-state value after the metabolic rearrangements are complete. The new co-repressor concentration may be too low to antagonize completely such a powerful inducer as IPTG, and yet be sufficient to counteract the weaker inducing properties of lactose.

Consideration of many of the results we have obtained, particularly those resulting from phosphate and adenine starvation in strain JC14, suggests that the catabolite co-repressor may not be derived from the carbon skeleton of glucose or other external repressing agent. The repression may depend, rather, on changes in the energy status of the cells resulting from the sudden onset of rapid metabolism. Mandelstam (1961) showed that repression by some substances was relieved by low concentrations of dinitrophenol, an uncoupler of oxidative phosphorylation. Those repressions which were relieved were all exerted by substances which are metabolized aerobically only; glucose and fructose, which can also be fermented, continued to repress in the presence of dinitrophenol. This may indicate that the catabolite co-repressor is closely dependent on ATP, since aerobic formation of ATP is sensitive to inhibition by dinitrophenol, whereas ATP formation at the substrate level, as in fermentation, is not. In some organisms it has been shown that metabolic inhibition with uncouplers has very little effect on the pool sizes of most intermediary compounds produced from glucose. In baker's yeast, for instance, the greatest decreases of pools by dinitrophenol were of those substances requiring ATP for their synthesis: UDP-glucose, other nucleotides and derivatives, and trehalose, the common disaccharide in yeast. By contrast, the pool sizes of sugar phosphates and of organic and amino acids were hardly affected
(Moses \& Smith, 1960). In another instance, the effect of azide on the metabolism of a filamentous fungus, a similar situation was found. In the latter case the disaccharide was maltose, and was similarly decreased in amount (Moses, 1959). Thus, unless the effect of dinitrophenol in $E$. coli is different from the fungi, it appears that changes in the concentrations of common catabolic intermediates derived from the carbon skeleton of glucose metabolism would not be sufficient to account for the relief of catabolite repression by dinitrophenol described by Mandelstam (1961).

Catabolite repression may in some cases be relieved by anaerobiosis (Cohn \& Horibata, 1959; Dobrogosz, 1965). This again suggests that the co-repressor is dependent on ATP, since the availability of ATP in the cell might be expected to fall considerably during anaerobiosis. These earlier observations fit in with the results reported in the present paper, particularly those with strain JC 14: relief of repression by glycerol during adenine and phosphate starvation (possibly resulting from a fall in the supply of ATP), and intense repression when these nutrients are restored, perhaps as a result of a rapid increase in the availability of ATP.

It seems likely therefore that the catabolite corepressor is a substance whose concentration is sensitively dependent on the availability of ATP. It could conceivably be ATP itself (Mandelstam, 1961), or a compound of the 'phosphagen' type, bearing a relation to ATP analogous to that of creatine and creatine phosphate in muscle. A mechanism for its action would then be as follows: the entry of glucose or other rapidly metabolizable substance into metabolism would suddenly increase the availability of ATP. The actual concentration of ATP may not in fact rise very much before a change in concentration of the co-repressor is triggered, and this might prevent a further change in ATP concentration. The rise in concentration of the co-repressor would stop the overall process of messenger RNA transcription for a sensitive category of operons which would include the lactose enzymes. After a certain period, the altered concentrations of these several compounds would revert to a greater or smaller extent towards the initial value, and a new steady state be achieved. This reversion would now permit some messenger RNA synthesis for the sensitive operons; how much RNA was made would depend on the extent of reversions and the sensitivities of the various operons.

It is well known that the introduction of 'luxury' quantities of carbohydrates and other nutrients to cells previously maintained on limited supplies results in a complex series of transient phenomena affecting the pool sizes of metabolic intermediates of carbohydrate metabolism as well as those of 
ATP and ADP (Calvin \& Massini, 1952; Wilson \& Calvin, 1955; Lonberg-Holm, 1959). These transients eventually disappear, resulting in a new steady-state concentration of metabolites. An explanation based on such transients of ATP or functionally related substances might be invoked to explain the recovery from catabolite repression which we have observed to occur spontaneously in every strain of $\boldsymbol{E}$. coli we have examined.

The temporary increase in the differential rate of RNA synthesis which follows the introduction of glucose is unlikely to be directly responsible for the inhibition of induced enzyme synthesis, even though the two processes are of about the same duration. Rather we might suppose that both are direct consequences of the metabolic readjustments.

It is not clear at this juncture how closely related is repression by glucose of the three catabolic enzymes studied in the present paper. The same metabolic product may or may not be responsible for repression for each of the enzymes; we also do not know whether there is a different regulatory site for each enzyme at which the corepressor operates. The three enzymes studied recover from repression at different times and to different extents. These observations may be tentatively explained in the following way. If the co-repressors for each enzyme are identical, or at least metabolically closely related, though the sensitivity of the regulatory site differs in each case, we may have a situation like that illustrated in Fig. 25. Addition of glucose results in a rapid increase in co-repressor concentration, which slowly falls to a new steady-state value somewhat higher

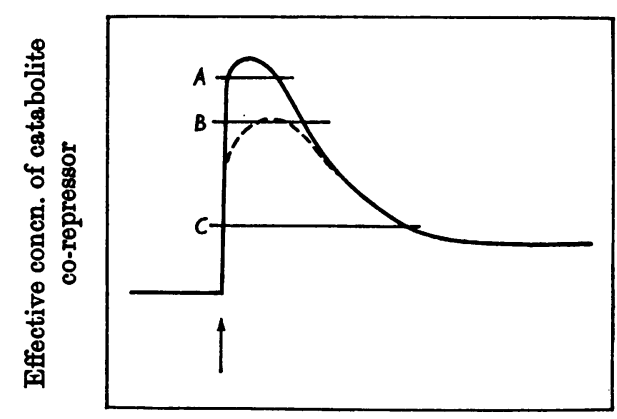

Time

Fig. 25. Proposed model for transient changes in corepressor concentration when glucose is added $(\uparrow)$. Corepressor concn. necessary to repress various enzymes as follows: $A$, lactose enzymes; $B$, galactose enzymes and serine deaminase; $C$, tryptophanase. Possible deviation from standard kinetio behaviour in mutant isolated by Loomis \& Magasanik (1965) is shown by the broken line (see the text). than that before glucose was introduced. The sensitivity to co-repressor concentration would be greatest for L-tryptophanase, intermediate for $D$-serine deaminase and least for $\beta$-galactosidase. The rapid rise in co-repressor concentration would repress the synthesis of each enzyme almost simultaneously, whereas the slow fall in concentration would permit relief of repression first for $\beta$-galactosidase, next for $\mathrm{D}$-serine deaminase and last for L-tryptophanase (cf. Fig. 24). The extent of the fall in co-repressor concentration would determine the degree of recovery of each enzyme. Since the co-repressor concentration would be related to the magnitude of the metabolic disturbance, which in turn would be reflected in the increase in the differential rate of RNA synthesis, we might note that in strains where RNA synthesis returned most closely to its original rate, enzyme synthesis recovered to the greatest extent (Figs. 16 and 18). In strain $A B 1105$ the extent of recovery of enzyme synthesis was least and the rate of RNA synthesis remained significantly elevated for a prolonged period (Fig. 19).

A number of examples have been reported in the literature of resistance to catabolite repression, at least as exerted by glucose. Some authors have failed to recognize a difference between resistance to catabolite repression generally and resistance to repression exerted by glucose specifically. This point has been fully discussed by Neidhardt (1960). Loomis \& Magasanik (1965) claimed to have isolated a mutant of $E$. coli specifically resistant to catabolite repression of $\beta$-galactosidase. Close examination of their results, however, reveals that in their mutant resistance was not restricted to $\beta$-galactosidase, although it was most pronounced for this enzyme: galactokinase also showed increased resistance. Further, though $\beta$-galactosidase was resistant to repression by glucose and glycerol, considerable sensitivity still remained with respect to gluconate and lactate. An alternative explanation of their observations is available in the mechanism shown in Fig. 25: an altered glucose metabolism (e.g. affecting the formation of gluconic acid; cf. Neidhardt, 1960) might fail to increase the effective concentration of co-repressor sufficiently to cause any inhibition of $\beta$-galactosidase synthesis. There may nevertheless be sufficient co-repressor to cause some repression of galactokinase synthesis, and total repression of the syntheses of maltase and L-tryptophanase, two other enzymes studied by Loomis \& Magasanik (1965).

RNA synthesis as a function of cell population density. The fall in the differential rate of RNA synthesis as a function of increasing cell density appears to be a real phenomenon. Explanations based on changes in the rates of utilization of external versus endogenous uracil have been 
excluded. We might consider three possible causes for this effect: the exhaustion of a nutritional factor in the medium, the excretion of an inhibitory factor into the medium, or the results of increased frequency of collision between cells as the population density increased. These have not yet been studied in detail, but it is worth noting that in spite of rapid stirring of the cultures, no dissolved oxygen was measurable in the culture with an oxygen electrode once the extinction exceeded about 0.5. Partial anaerobiosis might therefore have been a factor, although exponential growth was maintained. As far as cell density is concerned, Rao \& Bhargava (1965) have found with resting cells of $E$. coli that the specific rates of uptake from the medium of arginine and glucose decreased with increasing bacterial concentration.

From the data of the experiments reported in Figs. 20 and 22 it is possible to calculate the rate of RNA synthesis compared with the RNA preexisting in the population. We have found the total RNA ribose in $E$. coli to be $17 \mu \mathrm{g} . / \mathrm{ml}$. at an extinction of 1.0. From the averages of the base ratios for $E$. coli RNA published by Elson \& Chargaff (1955) and Belozersky \& Spirin (1958), in which uracil constitutes $20 \%$ of the total bases on a molar ratio, the uridine-ribose content would be $3.4 \mu \mathrm{g} . / \mathrm{ml}$., corresponding to $2.5 \mu \mathrm{g} . / \mathrm{ml}$. of uracil. (The total uracil content of the cells measured by the uptake of $\left[{ }^{3} \mathrm{H}\right]$ uracil from the medium by Ucells was $9 \cdot 3 \mu \mathrm{g} . / \mathrm{ml}$. at extinction 1.0 ; thus $27 \%$ of the total uracil was precipitable by trichloroacetic acid.) The cells were growing exponentially with a doubling time of $70 \mathrm{~min}$. Thus in $2 \mathrm{~min}$. the cells increased in mass by $2 \%$. Since the total RNA content per cell remained constant during exponential growth (Fig. 22), the amount of $\left[{ }^{3} \mathrm{H}\right]$ uracil incorporated into RNA during a $2 \mathrm{~min}$. period needed to be at least $2 \%$ of the pre-existing RNAuracil, simply to account for the net RNA synthesis during this time. The data presented in Table 2 show that during the early stages of growth the $\left[{ }^{3} \mathrm{H}\right]$ uracil incorporated in $2 \mathrm{~min}$. was actually about $12 \%$ of the pre-existing RNA-uracil, whereas at extinctions greater than 0.75 this had fallen to $2.5 \%$.

From these values we might conclude that in dilute cultures over $80 \%$ of the uracil incorporated in $2 \mathrm{~min}$. was located in a labile form of RNA which did not contribute permanently to the total RNA. Towards the end of the growth period only $20 \%$ of the incorporated uracil was found in unstable RNA.

Evidence has accumulated that messenger RNA, usually considered to be the most important component of labile RNA, is not necessarily all unstable (Moses \& Calvin, 1965b). It has been suggested that in bacteria unstable messenger RNA is associated particularly with operons under the repressible control of regulator genes, whereas more stable messenger functions may be characteristic of those structural genes which are not regulated in this way (Moses \& Calvin, 1965a; Yudkin, 1965). A consequence of the change of RNA stability with growth may be that the induction or de-repression of some enzymes dependent on labile messenger RNA may become progressively more difficult as the population density increases during

Table 2. Rate of RNA synthesis compared with total RNA content as a function of growth measured by extinction

Strain CR34 (uracil-requiring) was used. Uracil incorporated into RNA in 2 min. was measured at intervals and expressed as percentage of calculated pre-existing RNA-uracil. Total RNA content of the culture was directly proportional to extinction: $1 \mathrm{ml}$. of culture of extinction 1.0 contained $2.5 \mu \mathrm{g}$. of RNA-uracil $/ \mathrm{ml}$. (Fig. 22).

\begin{tabular}{|c|c|c|c|}
\hline Extinction & $\begin{array}{c}\text { Pre-existing } \\
\text { RNA-uracil } \\
(\mu \mathrm{g} \cdot / \mathrm{ml} .)\end{array}$ & $\begin{array}{c}\text { Uracil incorporated } \\
\text { into RNA/2 min. } \\
(\mu \mathrm{g} . / \mathrm{ml} .)\end{array}$ & $\begin{array}{l}\text { Uracil incor- } \\
\text { porated in } \\
2 \text { min. as \% of } \\
\text { pre-existing } \\
\text { RNA-uracil }\end{array}$ \\
\hline 0.046 & 0.115 & 0.0119 & $10 \cdot 3$ \\
\hline 0.056 & $0 \cdot 140$ & 0.0193 & $13 \cdot 8$ \\
\hline 0.068 & 0.170 & 0.0167 & $9 \cdot 8$ \\
\hline 0.091 & 0.228 & 0.0153 & $6 \cdot 7$ \\
\hline $0 \cdot 126$ & 0.315 & 0.0172 & $5 \cdot 5$ \\
\hline 0.165 & 0.413 & 0.0194 & $4 \cdot 7$ \\
\hline 0.227 & 0.568 & 0.0225 & $4 \cdot 0$ \\
\hline 0.301 & 0.753 & 0.0293 & $3 \cdot 9$ \\
\hline 0.409 & 1.023 & 0.0329 & $3 \cdot 2$ \\
\hline 0.578 & $1 \cdot 445$ & 0.0426 & $2 \cdot 9$ \\
\hline 0.750 & $1 \cdot 875$ & 0.0447 & $2 \cdot 4$ \\
\hline 1.028 & $\mathbf{2} \cdot 570$ & 0.0644 & 2.5 \\
\hline
\end{tabular}


exponential growth. Preliminary results from this Laboratory have suggested that this is indeed the case with L-tryptophanase, and phenomena of this sort have also been observed with various enzymes in several species of bacteria by Pinsky \& Stokes (1952) and by Nurmikko, Soini, Terho \& Kantonen (1964).

The work reported in this paper was sponsored by the U.S. Atomic Energy Commission. We thank Miss Pamela B. Sharp for invaluable technical assistance.

\section{REFERENCES}

Belozersky, A. N. \& Spirin, A. S. (1958). Nature, Lond., $182,111$.

Bernstein, I. A., Fossitt, D. \& Sweet, D. (1958). J. biol. Chem. 233, 1199.

Boezi, J. A. \& Cowie, D. B. (1961). Biophys. J. 1, 639.

Calvin, M. \& Massini, P. (1952). Experientia, 8, 445.

Clark, D. J. \& Marr, A. G. (1964). Biochim. biophys. Acta, 92, 85.

Clarke, P. H. \& Brammar, W. J. (1964). Nature, Lond., 203, 1153.

Cohen, S. S. \& Barner, H. (1955). J. Bact. 69, 59

Cohn, M. \& Horibata, K. (1959). J. Bact. 78, 624.

Dobrogosz, W. J. (1965). Biochim. biophys. Acta, 100, 553.

Elson, D. \& Chargaff, E. (1955). Biochim. biophys. Acta, $17,362$.

Gershanovich, V. N. (1962). Biokhimiya, 27, 1023.

Herzenberg, L. A. (1959). Biochim. biophys. Acta, 31, 525.

Jacob, F. \& Monod, J. (1961). J. molec. Biol. 3, 318.

Kepes, A. (1960). Biochim. biophys. Acta, 40, 70.

Kepes, A. (1963). Biochim. biophys. Acta, 76, 293.

Kinard, F. E. (1957). Rev. sci. Instrum. 28, 293.

Lovinthal, C., Keynan, A. \& Higa, A. (1962). Proc. nat. Acad. Sci., Wash., 48, 1631.

Lonberg-Holm, K. K. (1959). Biochim. biophys. Acta, 35, 464.

Loomis, W. F., jun. \& Magasanik, B. (1964). J. molec. Biol. 8, 417.

Loomis, W. F., jun. \& Magasanik, B. (1965). Biochem. biophys. Res. Commun. 30, 230.
Lowry, O. H., Rosebrough, N. J., Farr, A. L. \& Randall, R. J. (1951). J. biol. Chem. 193, 265.

Maaløe, O. \& Hanawalt, P. C. (1961). J. molec. Biol. 3, 144. McCarthy, B. J. \& Britten, R. J. (1962). Biophys. J. 2, 35.

McFall, E. \& Magasanik, B. (1960). Biochim. biophys. Acta, 45, 610 .

McFall, E. \& Magasanik, B. (1962). Biochim. biophys. Acta, 55, 900.

McFall, E. \& Mandelstam, J. (1963). Biochem. J. 89, 391.

Magasanik, B. (1963). In Informational Macromolecules, p. 271. Ed. by Vogel, H. J., Bryson, V. \& Lampen, J. 0. New York and London: Academic Press Inc.

Mandelstam, J. (1961). Biochem. J. 79, 489.

Monod, J. (1945). Ann. Inst. Pasteur, 71, 37.

Moses, V. (1959). J. gen. Microbiol. 20, 184.

Moses, V. \& Calvin, M. (1965a). In Evolving Genes and Proteins, p. 511. Ed. by Bryson, V. \& Vogel, H. J. New York and London: Academic Press Inc.

Moses, V. \& Calvin, M. (1965b). J. Bact. 80, 1205.

Moses, V. \& Smith, M. J. H. (1960). Biochem. J. 76, 585.

Nakada, D. \& Magasanik, B. (1964). J. molec. Biol. 8, 105.

Neidhardt, F. C. (1960). J. Bact. 80, 536.

Nurmikko, V., Soini, J., Terho, T. \& Kantonen, U. (1964). Acta chem. scand. 18, 627.

Paigen, K. (1964). Abstr. 6th int. Congr. Biochem., New York, IX-68.

Pardee, A. B. \& Prestidge, L. S. (1961). Biochim. biophys. Acta, 49, 77.

Pinsky, M. J. \& Stokes, J. L. (1952). J. Bact. 64, 337.

Putman, E. W. \& Hassid, W. Z. (1952). J. biol. Chem. 196, 749.

Rao, S. \& Bhargava, P. M. (1965). J. gen. Microbiol. 40, 219.

Schick, M., Landau, B. \& Tschudy, D. P. (1958). J. Bact. 75,414

Schneider, W. C. (1957). In Methods in Enzymology, vol. 3, p. 680. Ed. by Colowick, S. P. \& Kaplan, N. O. New York: Academic Press Inc.

Sypherd, P. S. \& Strauss, N. (1963). Proc. nat. Acad. Sci., Wash., 50, 1059.

Torriani, A. (1960). Biochim. biophys. Acta, 38, 460.

Torriani, A. \& Rothman, F. (1961). J. Bact. 81, 835.

Wilson, A. T. \& Calvin, M. (1955). J. Amer. chem. Soc. 77, 5948.

Yudkin, M. D. (1965). Biochim. biophys. Acta, 103, 705. 